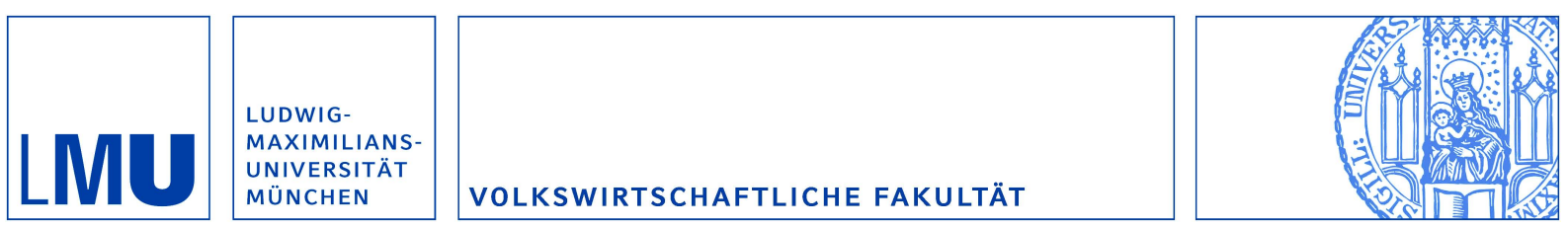

Semrad, Alexandra:

Modern secondary education and economic performance: the introduction of the Gewerbeschule and Realschule in nineteenth-century Bavaria

Munich Discussion Paper No. 2014-47

Department of Economics

University of Munich

Volkswirtschaftliche Fakultät

Ludwig-Maximilians-Universität München

Online at https://doi.org/10.5282/ubm/epub.21710 


\title{
Modern secondary education and economic performance: the introduction of the Gewerbeschule and Realschule in nineteenth-century Bavaria*
}

\author{
Alexandra Semrad ${ }^{\S}$
}

August 2014

Do new school types focusing on practical and business-related knowledge lead to increased economic performance? To analyze this question, this paper examines the introduction of two types of modern secondary education, the Gewerbeschule and its successor, the Realschule, in nineteenth-century Bavaria. Since opening of these schools is arguably endogenous - as it were mainly the prosperous, big cities that opened one - the estimated treatment effect capturing the economic influence of the Gewerbeschule/Realschule will lead to biased results. To alleviate this bias, I adopt propensity score matching to compare relatively alike counties with and without these schools. Using historical countylevel data on business formations, tax revenues, employment structure, and patent holdings, OLS regression analysis shows that the opening of a modern secondary school is in general positively associated with economic performance several years later.

\footnotetext{
*A more updated version of this article is forthcoming in The Economic History Review.

${ }^{\S}$ Munich Graduate School of Economics, University of Munich, Ludwigstr. 33, 80539 Munich, Germany. Email: alexandra.semrad@econ.lmu.de

I thank Davide Cantoni for many valuable comments and suggestions. I further thank three anonymous referees, Ludger Wößmann, Jochen Streb, Jörg Baten, Antonio Ciccone, and seminar participants at the University of Munich, Ifo Munich, University of Mannheim, University of Tübingen, the Arbeitstagung der Gesellschaft für Sozial- und Wirtschaftsgeschichte (Salzburg), the EDGE Jamboree (Cambridge), and the Economic History Society annual conference (Warwick) for helpful comments. The provision of data by Jochen Streb and Jörg Baten is gratefully acknowledged.
} 
The importance of human capital for economic development has been understood since the seminal works of Schultz ${ }^{1}$ and Gary Becker ${ }^{2}$ in the early 1960s. However, the positive role of education has mainly been ascribed to elementary schooling providing basic skills such as literacy. ${ }^{3}$ The role of secondary education is less clear and empirical results are more ambiguous. ${ }^{4}$

In this paper, I analyze the introduction of so-called 'modern secondary education' in Bavaria, i.e. the Gewerbeschule 5 , introduced in 1829 , and the Realschule, in 1877 , and their impact on economic performance.

The Gewerbeschule was introduced in several Bavarian cities between 1829 and 1835 and paved the way for modern secondary education: in contrast to the Gymnasium - the predominant type of secondary schooling at that time - which focused mainly on classical languages and abstract teaching of mathematics, the curriculum of the Gewerbeschule contained a high proportion of socalled "realistic" subjects such as modern languages and natural sciences. ${ }^{6}$ These skills were (and still are) considered important contributors to economic growth. In 1877 all 40 Gewerbeschulen were replaced by Realschulen. By 1907 there were more than 50 Realschulen on Bavarian soil. The curriculum introduced an obligatory third language, natural sciences, and a redefined focus on mathematics; moreover, three more years of schooling were added. ${ }^{7}$ Over the years, modern secondary education established itself as a popular alternative to traditional secondary education, i.e. Gymnasium.

Rudolf Diesel - the inventor of the Diesel engine - is a prominent example of a modern secondary school career: growing up in Paris, he convinced his parents to send him to Augsburg to

\footnotetext{
${ }^{1}$ See Schultz, 'Investment in human capital'.

${ }^{2}$ See Becker, Human capital.

${ }^{3}$ See Becker et al., 'Education and catch-up'. See also Easterlin, 'Why isn't the whole world developed?'

${ }^{4}$ Goldin studies the diffusion of secondary education across the United States during the first half of the twentieth century, also called the 'high school movement'. This study shows that expansion of school enrollment rates took place in relatively wealthy states lacking a large manufacturing sector since the availability of manual jobs increased youth's opportunity costs. Furthermore, empirical results indicate that returns to education were substantial at the beginning of the movement but mainly resulted from changing from manual to white-collar jobs. See Goldin, 'America's graduation', Goldin, 'Egalitarianism', and Goldin and Katz, 'Education and income'. For evidence on practice-oriented secondary education see Psacharopoulos and Patrinos, 'Returns'.

${ }^{5}$ Note that although Gewerbeschulen were called 'Landwirtschafts- und Gewerbeschulen' until 1864, in the following analyses I will use the term Gewerbeschule as an umbrella term.

${ }^{6}$ Döllinger, Sammlung, pp. 1691-8.

${ }^{7}$ Ministerialblatt (1877), pp. 197-205.
} 
attend the local Gewerbeschule where his uncle was a teacher. Still at the Gewerbeschule (between 1870 and 1873) he decided to become an engineer. Therefore, he continued to the Industrieschule and then to the Technische Hochschule in Munich to study industrial engineering. ${ }^{8}$ Other prominent former students of modern secondary education are Heinrich von Buz, industrialist and manager of MAN (Gewerbeschule Augsburg, 1845-9) ${ }^{9}$ and Friedrich Fischer, inventor, industrialist and founder of Kugelfabrik Fischer (Gewerbeschule Schweinfurt, ca. 1861-6). ${ }^{10}$

To assess the economic impact of modern secondary schooling, I employ county data on business formations, tax revenues, self-employed in trade and industry and employees in services and industry. In case of the Realschule, I use the number of granted patents as an additional measure of economic performance. All variables capturing economic performance are measured several years after the opening of a Gewerbeschule/Realschule to account for the fact that innovations in schooling might need some time to materialize in the economy. As the introduction of modern secondary education in a city is likely correlated with the city's current and future level of economic development, I employ propensity score matching following Rosenbaum and Rubin ${ }^{11}$ and Crump et al. $^{12}$

I can show that modern secondary education indeed had a positive impact on economic performance. Counties that introduced a Gewerbeschule by 1835 are associated with a significantly higher share of the population employed in industry in 1882, more tax revenues between 1881-4, and a higher per-capita number of business openings some forty years later than comparable counties without modern secondary schooling. Counties that opened a Realschule by 1896 have a higher share of the population employed in services and industry as well as a higher degree of innovativeness as captured by patents grants, several years later. These effects are all statistically significant even when accounting for a wide range of control variables.

This analysis contributes to the existing literature in several dimensions. In a broader context, it adds to the literature on the impact of schooling - and thus human capital - on economic growth.

\footnotetext{
${ }^{8}$ Diesel, Diesel, pp. 57-83; Luther, Rudolf Diesel, pp. 143-53.

${ }^{9}$ Luther, Heinrich von Buz, p. 133.

${ }^{10}$ Meer, Friedrich Fischer, pp. 237-8.

${ }^{11}$ See Rosenbaum and Rubin, 'Propensity score'.

12 See Crump et al., 'Dealing with limited overlap'.
} 
Human capital plays a prominent role in various growth models. In these models, human capital can either enter the production function on its $\mathrm{own}^{13}$ or by influencing the ability to absorb new technologies. Models of the last kind are based on the seminal work of Nelson and Phelps ${ }^{14}$; these models focus on the importance of human capital for technology diffusion: the higher the level of human capital in a country, the higher is the ability to adopt and implement new technologies and hence, the faster is the rate at which this country will catch up to the technological leader nation. Empirical applications of models in this spirit support the model predictions and reveal that the human capital stock determines income growth rates and thus convergence rates. ${ }^{15}$ However, there is also evidence that not only the initial level of human capital but also changes to it through education policies influence economic growth. ${ }^{16}$

One problem in the above named studies is that human capital is mainly proxied by years of schooling. ${ }^{17}$ For example, Easterlin compares primary school enrollment rates of several nations and concludes that expansion of schooling preceded economic growth. ${ }^{18}$ Walters and Rubinson focus on the impact of educational expansion on economic output in the United States from 1890 to 1969. They find time-specific economic effects of secondary and doctorate education. ${ }^{19}$ Barro shows that economic growth is positively associated with secondary and higher educational attainment of males. ${ }^{20}$ However, using this quantity measure of human capital might be misleading since 'years of schooling' yields no information about the educational value of schooling. Hence, Barro also adopts students' scores on internationally comparable examinations and finds that especially results in science tests are

\footnotetext{
${ }^{13}$ See for example Romer, 'Endogenous technological change' and Mankiw et al., 'Empirics of economic growth'. In Romer's model human capital is used in the research sector to produce new designs or generate new knowledge which in turn determines technological change. As a consequence, the larger the stock of human capital in the economy, the faster is economic growth as technological progress speeds up. Mankiw et al. use a Solow Model where they include human capital as an independent input factor in the production function. Comparing the standard Solow Model (Solow, 'Theory of economic growth') with their augmented version, they show that their model is able to explain cross-country variations in income far better than the standard model without human capital. They conclude that differences in education across countries can explain low levels of convergence in income between countries. However, In contrast to endogenous growth models such as Romer's, technology (and labor) is assumed to grow exogenously.

${ }^{14}$ See Nelson and Phelps, 'Investment in humans'.

${ }^{15}$ See Benhabib and Spiegel, 'Role of human capital'.

${ }^{16}$ See for example, Krueger and Lindahl, 'Education for growth'.

${ }^{17}$ For example, Barro uses school enrollment rates in 1960 to proxy human capital. However, he is well aware that this variable is not able to account for school quality. Therefore, he also adopts the student-teacher ratio yielding insignificant and ambiguous results. See Barro, 'Economic growth'.

${ }^{18}$ See Easterlin, 'Why isn't the whole world developed?'.

${ }^{19}$ See Walters and Rubinson, 'Educational expansion'.

${ }^{20}$ See Barro, 'Human capital'.
} 
strongly related to growth. ${ }^{21}$ This 'quality approach' to human capital is also supported by findings of Hanushek and Kimko who show that differences in the labor force quality are more able to explain growth rates than quantitative measures. ${ }^{22}$ In this context, Behrman and Birdsall argue that 'the incorporation of school quality into the analysis of income returns to schooling not only is theoretically plausible and of empirical importance, but may lead to better policy formulations in areas in which substantial scarce resources currently are being invested in poor countries, ${ }^{23}$ The role of school quality in historical economic development is also stressed by Easterlin who claims that 'the content of education conducive to economic growth is that of a secular and rationalistic type ${ }^{24}$

Literacy rates are commonly used in historical studies to proxy for the quality of human capital. For example, by analyzing Prussian county data, Becker and Woessmann find that predominantly Protestant counties took the lead in economic development due to their higher literacy rates and Becker et al. show that initially better educated regions - proxied by literacy - were able to catch up faster to the economic leader Britain. ${ }^{25}$ Cinnirella and Streb find that literacy had a positive influence on income as well as on innovative activities, which again raises income levels. ${ }^{26}$ This evidence suggests that basic education - providing kids with the knowledge to read - is decisive for economic development. However, as Barro demonstrates, there might also be an important role for secondary education. $^{27}$

Research on different types of secondary schooling in contemporary - mostly developing countries suggest that social and private returns of general academic education offset those of prevocational education. ${ }^{28}$ However, during industrialization, pre-vocational and practical education could have played a completely different role. In case of industrialization in England, the existence of

\footnotetext{
${ }^{21}$ Ibid.

${ }^{22}$ See Hanushek and Kimko, 'Schooling'. Focusing on school quality rather than quantity is also supported by Fuller et al., 'When does education boost economic growth?'. In this case study of Mexico between 1888 and 1940, they find that variation in educational quality (literacy levels) influences subsequent manufacturing output whereas educational quantity (school expansion) lacks economic impact.

${ }^{23}$ Behrman and Birdsall, 'Quality of schooling', p. 929.

${ }^{24}$ Easterlin, 'Why isn't the whole world developed?', p. 10.

${ }^{25}$ See Becker and Woessmann, 'Was Weber wrong?' and Becker et al., 'Education and catch-up'.

${ }^{26}$ See Cinnirella and Streb, 'Role of human capital'. Cinnirella and Streb use the number of high-valuable patents held in Prussian counties as a proxy for innovativeness. I will use this variable in the econometric specification in section III as an additional outcome variable.

${ }_{27}$ See Barro, 'Human capital'.

${ }^{28}$ See Bennell, 'General versus vocational'. See also Psacharopoulos, 'To vocationalize or not?' and Psacharopoulos and Patrinos, 'Returns'.
} 
private lecturers ${ }^{29}$, mechanics institutes ${ }^{30}$, and other intellectual associations illustrate that society clearly demanded technical and scientific education. ${ }^{31}$ Scientific associations and polytechnic societies also existed in nineteenth century Germany. Especially in Bavaria, these organizations thrived during the nineteenth century reflecting a demand for practical knowledge. ${ }^{32}$

This paper also complements to the literature on the evaluation of the Bavarian schooling system during the nineteenth century. While there exist several narrative studies concerning the Prussian higher education system ${ }^{33}$, only Buchinger provides an in-depth analysis of modern secondary education in Bavaria. ${ }^{34}$ However, his analysis does not explore any economic effect of these schools. To the best of my knowledge, this paper provides the first econometric analysis of the impact of specific Bavarian school types, in this case the Gewerbeschule and Realschule, on economic outcomes.

By focusing on Bavaria, I circumvent the problems associated with cross-country analyses: since comparing different counties within one sovereign territory, there are no major institutional, cultural, geographical or technological differences between these counties. Furthermore, Bavaria provides an interesting example to study the economic impact of educational innovations. As a state relying mostly on the agrarian sector, it was relatively backward in economic terms - especially when compared to Prussia - and available secondary schooling (i.e. Gymnasium) lacked practical orientation. ${ }^{35}$ Hence, the introduction of the Gewerbeschule and Realschule as new school types focusing on scientific content and its practical application provides the unique opportunity to assess the impact of innovations in education on the economy.

The remainder of the paper is structured as follows: First, an overview of the German educational system during the nineteenth and early twentieth century is given. A special emphasis is

\footnotetext{
${ }^{29}$ For example, John Banks gave lectures in Manchester on mechanics during the late eighteenth century. His lectures and books focused on solving problems commonly encountered by engineers and on increasing the mechanical knowledge of his audience (Musson and Robinson, Science and technology, p. 107).

${ }^{30}$ Mechanics institutes evolved in English towns during the late nineteenth century and offered instruction and practical application of science to the working class (Mitch, 'Role of education', pp. 248-9). For example, there existed 39 mechanic institutes in Liverpool in 1850 (Inkster, Science and technology, p. 79).

${ }^{31}$ Musson and Robinson, Science and technology, p. 113; Mitch, 'Role of education', pp. 248-51

${ }^{32}$ Buchinger, Geschichte der Realschule, pp. 108-10.

${ }^{33}$ See especially Punke, 'Recent developments I'; idem, 'Recent developments II'. See also Ringer, 'Higher education'; idem, Education and society; Kraus, Kultur.

${ }^{34}$ See Buchinger, Geschichte der Realschule.

${ }^{35}$ Ibid., pp. 106-12.
} 
thereby placed on the Bavarian schooling system. Moreover, this section explores the channel through which the Gewerbeschule and Realschule might influence the economy. This is followed by an introduction of the empirical model and a description of the data. The next section discusses the endogeneity associated with the opening of a modern secondary school and introduces an empirical approach to deal with this problem. The subsequent section presents the empirical results. The final section concludes.

\section{II.}

The most important form of German secondary schooling ${ }^{36}$ throughout the nineteenth century was the Gymnasium. ${ }^{37}$ Children usually transferred around age eleven after primary education - acquired either at a public school ('Volksschule') or private institution ('Vorschule') - to the Lateinschule. ${ }^{38}$ Students were required to complete this four-year institution (after 1874: five-year) in order to be entitled to attend the four-year Gymnasium. Thus, after completion of the Gymnasium students were about 18 to 20 years old (depending on the respective decade). The curriculum of the Gymnasium focused on the classical languages Greek and Latin and abstract teaching of mathematics. The Gymnasium understood itself as an institution providing higher general, religious and moral education and preparing students for independent studies at the university. ${ }^{39}$ Throughout the 19th century, only the Gymnasium possessed the right to confer the Abitur - a prerequisite for university admittance. ${ }^{40}$ Consequently, the Gymnasium was seen as an institution for the elite, raising a new generation of state officials, academics and clerics. ${ }^{41}$

The Realschule as a lower type of secondary education emerged during the eighteenth century in Prussia. Inspired by Hecker's 'ökonomisch-mathematische Realschule' founded in Berlin in 1747, six-year Realschulen were opened all over Germany. The educational objective of the Realschule was

\footnotetext{
${ }^{36}$ Note that during the 19 th and early 20th century, schools were separated by gender. Secondary education was more common for boys; girls rarely continued to secondary schools after primary education. Except for the Vorschule and Volksschule, all schools named in this paper were only open to boys.

${ }^{37}$ Ringer, 'Higher education', p. 128.

${ }^{38}$ Punke, 'Recent developments I', p. 576; Ringer, Education and society, p. 33.

${ }^{39}$ Ministerialblatt (1874), p. 327.

${ }^{40}$ Ringer, Education and society, p. 34; Kraus, Kultur, p. 42.

${ }^{41}$ This perception is confirmed by the fact that the majority of students at the Gymnasium came from high socioeconomic backgrounds (i.e. state officials, academics, physicians, artists, military, teachers, church and civil services). See BSKB, XXVIII (1873).
} 
to provide prevocational as well as general education, thereby focusing on mathematics, natural sciences, and modern languages such as English and French. ${ }^{42}$

Especially in Bavaria, Realschulen were quite popular already at the beginning of the nineteenth century - although by no means as popular as the Gymnasium as the predominant type of secondary education. Between 1808 and 1816 there existed Realschulen focusing on technical education and preparing for transfer to Realinstitute which in turn entitled for university studies. In 1816 these early Realschulen were transformed into Höhere Bürgerschulen which combined general education and occupational training and Realinstitute were closed. ${ }^{43}$ These Höhere Bürgerschulen were then replaced by Gewerbeschulen.

The Gewerbeschule was officially introduced in 1829 by the Bavarian King Ludwig I, who commanded the opening of a Gewerbeschule in all big cities of Bavaria ${ }^{44}$; in these cities, Bürgerschulen should be transformed into Gewerbeschulen. ${ }^{45}$ Gewerbeschulen were set up in close cooperation with industrial and trade associations. These groups were not only supposed to support the state in financing Gewerbeschulen but also to manage these schools together with state officials. ${ }^{46}$ Hence, these associations - or lobby groups - played a decisive role in the emergence and management of modern secondary education.

Gewerbeschulen were designed as three-year schools and pupils directly transferred to them after having completed the Volksschule around age twelve. ${ }^{47}$ A degree of the Gewerbeschule entitled to transfer to the Polytechnische Schule. This institution prepared for studies at the Technische Hochschule (i.e. a technical university) until they were replaced by Industrieschulen in $1868 .{ }^{48}$ Since the original curriculum of 1833 mainly provided a technical education - which clearly differentiates them from former Bügerschulen - these early Gewerbeschulen can be understood as professional schools. ${ }^{49}$ Furthermore, Gewerbeschulen had to include an agricultural department ${ }^{50}$; thus they were

\footnotetext{
${ }^{42}$ See Hecker, Kurzer Abriß. See also Hamann, Geschichte des Schulwesens, pp. 95-8.

${ }^{43}$ Buchinger, Geschichte der Realschule, pp. 76-9.

44 'In allen größeren Städten des Reichs sollen nach und nach Gewerbsschulen angelegt werden, zu deren Erhaltung angemessene Beiträge aus dem Staatsvermögen geleistet werden' (Döllinger, Sammlung, p. 1691).

${ }^{45}$ Buchinger, Geschichte der Realschule, p. 127.

${ }^{46}$ Döllinger, Sammlung, pp. 1691-2.

47 Ibid., p. 1692.

${ }^{48}$ Buchinger, Geschichte der Realschule, pp. 123-8; Regierungsblatt (1868), pp. 1698-1700.

${ }^{49}$ Buchinger, Geschichte der Realschule, pp. 127-8.

${ }^{50}$ Regierungsblatt (1830), pp. 183-6.
} 
called 'Landwirtschafts- und Gewerbeschulen'. Table 1 illustrates the official curriculum for students of the Gewerbeschule. Besides the courses in Table 2, students had to visit the so-called 'Realienunterricht' - i.e. general education - at a Gymnasium as depicted by Table 2.

Table 1

Table 2

By the school year of 1835/1836, 30 Landwirtschafts- und Gewerbeschulen existed in Bavaria. ${ }^{51}$

The technical orientation and the corresponding lack of general education of the Landwirtschafts- und Gewerbeschulen were widely criticized. Especially the rectors of the Bürgerschulen that had to be transformed into Gewerbeschulen stressed the importance of general education. As a consequence, the curricula of many Gewerbeschulen deviated from the official curriculum (cf. Table 1 and 2) already in $1833 .{ }^{52}$ For example, the syllabus of the Gewerbeschule in Kaiserslautern contained eleven hours per week of French but only three hours of chemistry. ${ }^{53}$

In 1864, Landwirtschafts- und Gewerbeschulen were substantially reformed. The weekly hours devoted to general education in form of the 'Realienunterricht' were expanded. The resulting school henceforth only called Gewerbeschule - provided general education and prepared for commercial and industrial professions. ${ }^{54}$ In order to meet the specific needs of their local environment, Gewerbeschulen were free to set up agricultural and commercial departments. ${ }^{55}$ Table 3 shows the curriculum of the reformed Gewerbeschule. The curriculum consisted of courses for all students (first eight subjects) and of courses depending on the respective departments.

\section{Table 3}

As Table 3 illustrates, Gewerbeschulen now combined general education with specific department related - subjects. Hence, as Kleinfeller - a contemporary witness - points out, the

\footnotetext{
${ }^{51}$ Döllinger, Sammlung, pp. 1625-6.

${ }^{52}$ Buchinger, Geschichte der Realschule, pp. 127-9.

${ }^{53}$ Ibid., p. 136.

${ }^{54}$ Regierungsblatt (1864), p. 546.

${ }^{55}$ Ibid., pp. 546-8; Buchinger, Geschichte der Realschule, pp. 153-9.
} 
reformed Gewerbeschulen were in fact schools focusing on general secondary education, i.e. the definition of a Realschule. ${ }^{56}$

In 1877, all three-year Gewerbeschulen were officially transformed into six-year Realschulen. Realschulen were supposed to provide higher civic education on the basis of modern languages, mathematics, sciences and history. The curriculum of the Realschule now included an obligatory third language (in this case English), a redefined focus on mathematics and natural sciences such as physics, as well as physical training. ${ }^{57}$ Table 4 gives the curriculum of the Realschule. This curriculum was more or less effective throughout the existence of the Realschule ${ }^{58}$ which lasted until 1907 when it was integrated into the new system of Oberrealschulen. ${ }^{59}$

\section{Table 4}

Table 5 shows the curriculum of traditional secondary education, i.e. the Lateinschule and Gymnasium, from 1874 onwards. ${ }^{60}$ Admittance to the Gymnasium required that students visited a Lateinschule first. ${ }^{61}$ Thus, in combination with the Lateinschule, the Gymnasium comprised three more classes than the Realschule, making it a nine-year institution. Students started both school types - modern and traditional secondary education - around age eleven; hence, at graduation, students were on average 16 in the Realschule and 19 in the Gymnasium. ${ }^{62}$

\section{Table 5}

Comparing the curricula of modern with traditional secondary education implicates that modern secondary education placed a greater emphasis on scientific subjects and modern languages: the Realschule devoted more weekly hours to mathematics, arithmetic, and physics - these were even combined to one subject in the traditional schools - and taught more hours of French than the

\footnotetext{
${ }^{56}$ Kleinfeller, Realschulen, pp. 39-40.

${ }^{57}$ Ministerialblatt (1877), pp. 197-255.

${ }^{58}$ In 1894, this curriculum was slightly reformed. For instance, calligraphy was added to the schedule of classes 1 and 2 and writing as an independent subject was removed from the curriculum. See Ministerialblatt (1894), p. 292.

${ }^{59}$ Ministerialblatt (1907), pp. 325-37.

${ }^{60}$ In 1891, this curriculum was slightly reformed. Weekly hours devoted to Latin and calligraphy were cut and nature study and graphics were added to the curriculum. See Ministerialblatt (1891), pp. 241-62.

${ }^{61}$ Ministerialblatt (1874), pp. 323-63; Ministerialblatt (1891), pp. 238-62; Ministerialblatt (1894), pp. 189-215.

${ }^{62}$ For admission, children had to be between nine and eleven in the Gymnasium and between ten and twelve in the Realschule. See Ministerialblatt (1874), p. 344; Ministerialblatt (1877), p. 204; Ministerialblatt (1891), p. 262; Ministerialblatt (1894), p. 310.
} 
Gymnasium. English and chemistry were absent from the obligatory curriculum of the Gymnasium, whereas Latin and Greek clearly dominated the curriculum.

After the Realschule, children could transfer to the Industrieschule. This institution was established as a replacement of the Polytechnische Schulen in 1868 and served as a technical middleschool building up on the Gewerbeschule and later on the Realschule. Pupils were either prepared for consecutive studies at the Technische Hochschule (after having passed the final exam at the end of the second year) or for a career in business and industry (after three years of schooling). The Industrieschule comprised three departments focusing on mechanical, technical, and constructional techniques. ${ }^{63}$ Hence, modern secondary education provided an alternative in entitling for university studies (however, only at the technical university). In 1907, Industrieschulen were replaced by Oberrealschulen.

These Oberrealschulen resulted from integrating Realschulen and Industrieschulen into one school type. Oberrealschulen included nine classes and entitled students for general university admittance. Thus, Oberrealschulen were on equal footing as Gymnasien. ${ }^{64}$

The Bavarian schooling system also comprised Realgymnasien which can be understood as a compromise between traditional and modern secondary education. Since there existed only four institutions - Augsburg, Munich, Nuremberg, and Wuerzburg - this institution played a rather minor role in secondary education. ${ }^{65}$ Figures 1 and 2 summarize the Bavarian schooling system from 1833 to 1876 and 1876 to 1907 , respectively.

Figure 1

Figure 2

All in all, modern secondary schooling in form of the Gewerbeschule and Realschule provided general education preparing for commercial and industrial professions; the focus on modern languages, applied mathematics, and natural sciences uniquely differentiates this school type from the traditional Gymnasium. In contrast to the Gymnasium as an institution mainly preparing for

\footnotetext{
${ }^{63}$ Regierungsblatt (1868), pp. 1698-1700.

${ }^{64}$ Buchinger, Geschichte der Realschule, pp. 105-12; Ministerialblatt (1907), pp. 325-37.

${ }^{65}$ Buchinger, Geschichte der Realschule, p. 153; Regierungsblatt (1864), pp. 538-44.
} 
consecutive university studies, the Realschule and Gewerbeschule prepared its students for both, technical studies and the (industrial and mercantile) labor market.

The educational system of 19th century Germany was subject to profound changes reflecting political, economic and social struggles and movements of that time ${ }^{66}$; thus, the formation of new forms of secondary schooling such as the Realschule, Realgymnasium, Oberrealschule, the Industrieschule and Gewerbeschule can only be understood in light of these movements. As the Gymnasium with its emphasis on classical languages could not offer an education preparing for commercial and industrial occupations, the mercantile middle class demanded the introduction of socalled modern schools: the curricula should focus more on modern languages, mathematics, and natural sciences. ${ }^{67}$ These demands were supported by an increasing number of critics who claimed that traditional schools such as the Gymnasium or Lateinschulen could not prepare its pupils for the changes taking place in the scientific, technical, industrial, and commercial environment of that time. ${ }^{68}$

Support also came from polytechnic advocacy groups promoting general technical education through journals, lectures, exhibitions, prize competitions and also by setting up special libraries. ${ }^{69}$ In Bavaria for instance, industrial, polytechnic, and agricultural associations as well as representatives of industry and commerce, individual persons and the press lobbied for a scientific-technical education in form of Gewerbeschulen, Realschulen, and Industrieschulen. A profound scientific-technical education of the labor force was expected to stimulate the economy. ${ }^{70}$ The important role of industrial and trade groups in modern secondary education is also manifested by the fact that these groups helped to manage and finance early Gewerbeschulen. ${ }^{71}$

According to Kleinfeller, the majority of modern secondary graduates started working in businesses and industrial occupations directly. ${ }^{72}$ As Ringer shows for Prussia in the years between 1875 and 1899 , most graduates of modern schools intended to seek positions in technical occupations such as engineering, mining and architecture or in commerce and industry. In contrast, only a minority

\footnotetext{
${ }^{66}$ Jeismann, 'Schule', p. 152.

${ }^{67}$ Buchinger, Geschichte der Realschule, pp. 93-112; Hamann, Geschichte des Schulwesens, pp. 95-6; Ringer, 'Higher education', p. 128.

${ }^{68}$ Albisetti, 'Debate', p. 182.

${ }^{69}$ Kraus, Kultur, p. 39-40.

${ }^{70}$ Buchinger, Geschichte der Realschule, pp. 108-9.

${ }^{71}$ Döllinger, Sammlung, pp. 1691-2.

${ }^{72}$ Kleinfeller, Realschulen, pp. 97-101.
} 
of graduates of the traditional Gymnasium opted for a technical profession or a career in commerce and industry. ${ }^{73}$

This is also illustrated by Table 6 which provides information about career choices of graduates of the Realschule Munich between 1878 and 1883. Since the Realschule was introduced in 1877/78, graduates of 1878 obtained their education predominantly at the predecessor institution, i.e. the Gewerbeschule. Graduates of 1883 are the first ones to pass through all six classes of the Realschule. The numbers implicate that over the years, more and more students opted for careers in trade, commerce, and industry. Since the number of graduates remained nearly constant over time, this increasing interest in mercantile and industrial careers suggests that the education of the Realschule encouraged young people to work in these sectors more than the Gewerbeschule did. Of course, Munich is not a representative case. Being the largest and economically most advanced city in Bavaria, it offered a wide range of job opportunities. However, as Buchinger argues, the fact that Munich was also not comparable to other Bavarian cities in terms of the provision of different kinds of secondary schools ${ }^{74}$, shows that the Realschule was able to compete with other secondary school types - as the following student numbers illustrate - and prepare its students for industrial, commercial and trade professions. ${ }^{75}$

\section{Table 6}

Education and practical knowledge of Realschule graduates were highly acknowledged by the business environment: merchants, manufacturers, master craftsmen, and other businessmen frequently asked rectors of Realschulen to recommend graduates of their institutions to them. These graduates were also better able to climb the career ladder due to their valuable knowledge obtained at the Realschule. $^{76}$

However, in order to determine the effect of modern secondary education on economic outcomes, precise information about the educational background of the people employed in industrial and trade-related occupations some years after the introduction of these modern schools is needed.

\footnotetext{
${ }^{73}$ Ringer, Education and society, pp. 71-9.

${ }^{74}$ For instance, by 1905/06, Munich had four Realschulen, five Gymnasien, and one Realgymnasium. See Ministerialblatt (1906), pp. 16-5.

${ }^{75}$ Buchinger, Geschichte der Realschule, p. 173.

${ }^{76}$ Kleinfeller, Realschulen, pp. 101-4.
} 
In absence of this information, career aspirations and the number of students attending modern secondary education are indispensable factors in the analysis. It can be supposed that there is a link between the strength of the effect of the school on economic outcomes and the number of students at this school. The following table lists the number of students attending secondary schools from 1834 to 1907 in total as well as per 1,000 people.

\section{Table 7}

According to Table 7, an increasing number of children continued to secondary education between 1834 and 1907. Except for the school year of 1841/42 and 1906/07 in case of modern secondary education and 1862/63 in case of traditional secondary education, total student numbers as well as students per 1,000 people rose continuously in both school types. The first years after the Gewerbeschule was introduced, the overall number of students as well as the number of schools declined. However, after 1851/52 student and school numbers of modern secondary education rose steadily - exceeding even those of the traditional Gymnasium in the 1860s and early 1870s. In the closing year of the Gewerbeschule, i.e. 1876/77, 5,375 children attended altogether 40 schools - a number almost four times larger than that of the second school year after its introduction, i.e. 1834/35. This increase is even more remarkable since the number of schools did not even double between these thirty years. The Realschule started with 7,685 students and 40 schools in 1877/78 and experienced a constant increase in both students and schools. In the last year of its existence - before it was converted into the Oberrealschule - 14,031 children attended altogether 55 schools.

The increase of student numbers at the traditional Gymnasium is almost as extreme as that of the Gewerbeschule/Realschule: numbers rose from less than 3,000 in 1871 to almost 20,000 students in 1907. A large fraction of this increase can be attributed to the extension of the Gymnasium from a six-year to a nine-year institution in 1874 (including the Lateinschule). Another reason for this huge difference in student numbers after 1873 is that in case of modern secondary education, counties were sometimes allowed to open three-year instead of six-year Realschulen. ${ }^{77}$

\footnotetext{
${ }^{77}$ For instance, in 1885/76, 13 out of 46 Realschulen only offered four classes (Ministerialblatt 1885, pp. 278-9). Students could transfer after these four years to six-year Realschulen in other counties (Ministerialblatt 1877, $\mathrm{p}$. 201). See also Ministerialblatt (1894), p. 289.
} 
Altogether, the almost constant increase of student and school numbers - besides the slight cutback in the 1840s in case of the Gewerbeschule - demonstrates the rise of both modern and traditional secondary education. The fact that graduates of modern secondary education mainly pursued industrial and business-related careers and were highly esteemed by the local business environment suggests that these schools could have had a positive effect on the economy. This economic role of the Gewerbeschule and Realschule will be analyzed empirically in the subsequent chapters.

\section{III.}

In this paper, I compare counties with a Gewerbeschule or Realschule to counties without modern secondary schooling. The implicit assumption underlying the subsequent analysis is that students of modern secondary education do not leave counties after education in order to seek employment or start businesses in other counties. This migration would bias the modern secondary education effect presumably - downwards if former students settled in counties without this school type. If, however, these students decided to move to counties that also offered modern secondary education, the estimates would remain unbiased. Due to data limitations there is no possibility to control for migration. However, it is likely that migration does not severely bias the estimates. First - as the examples of Heinrich von Buz, Friedrich Fischer, and Rudolf Diesel illustrate - most former students probably stayed in the city where they obtained their education. Second, since children started modern secondary education already at age eleven, it seems unlikely that they were sent from towns without to towns with a Gewerbeschule/Realschule in many cases - Rudolf Diesel being a prominent exception. Thus, the problem resulting from moving back to their home towns after graduation remains in my opinion relatively small. However, I will account for the potential bias induced by migration by using data reflecting the overall level of mobility in the counties. Therefore, I run regressions weighted by the share of non-immigrants and the share of people born in municipality in case of the Gewerbeschule and Realschule, respectively. ${ }^{78}$

\footnotetext{
${ }^{78}$ Using these weights ensures that counties with high migration patterns will receive lower weights in the estimation of a modern secondary education effect.
} 
Did the introduction of modern secondary schooling boost economic performance? To answer this question I separately estimate the following models in case of the Gewerbeschule and Realschule:

$$
y=\alpha+\beta * \operatorname{ModSec}+\boldsymbol{\Gamma} \boldsymbol{X}+u
$$

where $y$ is a per-capita measure of economic performance and $\boldsymbol{X}$ is a set of control variables including geography, administrational independence, religious shares, other schools, and advocacy groups. ModSec is a dummy variable indicating whether there was a Gewerbeschule in 1835 or Realschule in 1896 in the respective county. Hence, $\beta$ is the coefficient of interest capturing the economic effect of modern secondary education.

However, as mentioned above, assignment of these schools to counties did not occur randomly, thereby limiting the validity of the estimated treatment effect. I will account for this problem by sample restriction using propensity scores in section IV.

The main source of data is taken from censuses conducted by the royal Bavarian statistical office ('Königlich-Bayerisches Statistisches Bureau') between 1850 and 1907 and its predecessor institutions. ${ }^{79}$ These censuses were either published in 'Beiträge zur Statistik des Königreiche Bayern' (BSKB) or in 'Zeitschrift des Königlich Bayerischen Statistischen Bureau' (ZKBSB). Description and source of the employed data is listed in Table A1 in the Appendix; summary statistics are given in Table A2 in the Appendix.

Counties. The observational unit is a county ('Bezirksamt') implying that cities and their respective counties are combined to one observational unit, i.e. county. This applies to all variables: population numbers, existing schools ${ }^{80}$, and measures of economic performance. There are two reasons for merging cities and corresponding counties: first, this allows for the possibility that children from the surrounding countryside visited city schools and second, it can be supposed that any economic effect of modern secondary schooling was not only restricted to the city, but also to the proximate rural districts. As stated above, the available data does not allow controlling for migration of graduates between counties.

\footnotetext{
79 For more details on the history of the royal Bavarian statistical office see: https://www.statistik.bayern.de/ueberuns/geschichte/

${ }^{80}$ For instance, the city of Munich opened a Gewerbeschule in 1833 and therefore the whole observational unit consisting of the city and its two counties is counted as having a Gewerbeschule.
} 
Gewerbeschule. Gewerbeschulen were first introduced in Bavaria 1833 as 'Landwirtschaftsund Gewerbeschulen'. By 1835 there were a total of 30 Gewerbeschulen in Bavaria. The data is based on Gewerbeschulen that received district funds and revenues generated by funds of former Bürgerschulen in 1835 as listed in Döllinger. ${ }^{81}$ By 1871 there existed 36 Gewerbeschulen. The information on Gewerbeschulen in 1871 originates from educational censuses. I restrict my sample to those counties that either had a Gewerbeschule both in 1835 and 1871 and to counties that had no Gewerbeschule both in 1835 and 1871. Therefore, counties that set up or closed a Gewerbeschule in the years between 1836 and 1870 are excluded from the sample. ${ }^{82}$ In sum four towns closed ${ }^{83}$ and ten opened Gewerbeschulen ${ }^{84}$ and are consequently disregarded from the Gewerbeschulen sample. Hence, the sample includes 26 cities with a Gewerbeschule.

Since the observational unit is a county, once a city opens a Gewerbeschule, the respective observational unit "county" is counted as having a Gewerbeschule. Counties with a Gewerbeschule in 1835 and 1871 are shown in the Appendix by Figure A1 and A2, respectively. The dots without a name correspond to the counties in the control group.

Realschule. Realschulen were introduced in 1877 in Bavaria and replaced all existing 40 Gewerbeschulen. By the school year of 1906/07 another 15 Realschulen had been opened in 13 counties. Except for Munich and Nuremberg ${ }^{85}$ - which opened additional Realschulen - all new Realschulen were opened in cities that previously had not offered modern secondary education. Unlike the Gewerbeschule, there is no case of a Realschule documented that had to close in the subsequent years. The data is based on publications of the Bavarian Ministry of Interior and Education. Counties

\footnotetext{
${ }^{81}$ Döllinger, Sammlung, pp. 1625-6.

${ }^{82}$ Counties are only excluded if the closure lasted more than five years. For instance, Kaufbeuren closed its Gewerbeschule between 1839 and 1841 (Buchinger, Geschichte der Realschule, p. 140) and will consequently not be excluded from the sample.

${ }^{83}$ Burghausen, Dillingen, Rothenburg, and Schwabach had to close their schools in the following years (Ibid., p. 139-40). Only Rothenburg reopened its school in 1865 (Keyser, Bayerisches Städtebuch 2, p. 278) but will nevertheless also be excluded from the sample since the timespan of closure exceeded five years.

${ }^{84}$ Counties that set up a Gewerbeschule between 1836 and 1871 are: Dinkelsbühl (opened 1869; Keyser, Bayerisches Städtebuch 1, p. 158), Ingolstadt (1858; idem, Bayerisches Städtebuch 1, p. 471), Kissingen (opened 1871; idem, Bayerisches Städtebuch 1, p. 82), Kitzingen (opened 1871; idem, Bayerisches Städtebuch 1, p. 82), Lindau (opened 1859; idem, Bayerisches Städtebuch 2, p. 349), Memmingen, Neuburg (opened 1859; idem, Bayerisches Städtebuch 1, p. 458), Neustadt a.d.H. (opened 1869; idem, Städtebuch Rheinland-Pfalz, p. 317), Rothenburg (1865; idem, Bayerisches Städtebuch 2, p. 278), and Weiden (opened 1869; idem, Bayerisches Städtebuch 2, p. 729).

${ }^{85}$ In 1906/07 Munich had four and Nuremberg two Realschulen. See Minsterialblatt (1906), pp. 21-2.
} 
with a Realschule in 1878 and 1896 are shown in the Appendix by Figure A3 and A4, respectively. The dots without a name correspond to counties in the control group.

Other Controls. Data on population numbers are taken from censuses conducted on a county basis in Bavaria in 1840, 1871, 1880, and 1905. These censuses also state religious affiliations of the population. Becker and Woessmann show that Protestantism led to higher literacy in Prussian counties - imposed by the need to be able to read the Bible - explaining the lead of Protestant counties in economic outcomes in nineteenth century Prussia. ${ }^{86}$ The reported summary statistics in Table A2 reveal that counties introducing modern secondary education were on average dominated by Protestants. Disregarding religious denominations might lead to omitted variable bias if certain religions might also affect economic prosperity. Thus, I include the population shares of Jews and Protestants as control variables.

As outlined in section II, industrial and trade associations played a decisive role in modern secondary education. Hence, I control for these lobby groups by using numbers on advocacy groups lobbying for science, economy and education in 1839 (Gewerbeschule) and 1872 (Realschule).

Other controls include administrational independence in 1830,1871, 1896, and 1906, a dummy for the Bavarian Palatinate, an exclave lying west of the Rhine, the presence of Gymnasien in 1862, 1871 and 1906, and of savings banks in 1835 .

Economic Performance. Investments in schooling can be supposed to have a lagged effect on the economy. Therefore, I focus on measures capturing economic performance with a time lag. As outlined in section II, the curricula of modern secondary education focused on applied teaching of mathematics such as commercial arithmetic and modern languages; hence I adopt measures capturing the trade business environment. Furthermore, the curricula included subjects that can be supposed to be beneficial for industrial occupations such as graphics, chemistry, and natural science; hence I also use measures of industrial performance.

In case of the Gewerbeschule I use four measures: the average number of businesses registrations per year, the number of self-employed in industry and trade, tax revenues, and the number of employees in services and industry. The average number of new trade businesses per year

\footnotetext{
${ }^{86}$ See Becker and Woessmann, 'Was Weber wrong?'.
} 
is captured by taking the average difference between the number of registrations and closures within one year in one county ('Handelsgewerbebewegung'). I focus on the time period between 1869 and 1875. The data are taken from industrial censuses. The number of business registrations within one year provides information about the dynamics and quality of the business environment and hence is a proxy for economic performance of a county. The number of self-employed in 1871 and the data on employees in industry and services in 1882 are taken from occupational censuses. It can be supposed that the higher the number of people self-employed in industry and trade as well as people working in services and industry, the higher the industrial development of a county. The average value of expected tax revenues ('Steuer-Soll') between 1881 and 1884 stems from publications on the Bavarian state budget. These publications report expected tax revenues - i.e. direct state income taxes - per county (in Mark). ${ }^{87}$ Direct taxes in nineteenth-century Bavaria were taxes on land, houses, trade, capital, and income. ${ }^{88}$ These taxes are good proxies for economic development. ${ }^{89}$

In case of the Realschule I also use three measures ${ }^{90}$ : the number of trade and industrial businesses, the number of employees in trade and industry, and the average number of new patents. I concentrate on the number of existing businesses in 1907 in two main categories, i.e. trade and industry. I suppose that counties with a Realschule had more businesses and people employed in these sectors as modern secondary schools provided educational training required for these occupations. The data on businesses and employees is taken from the establishment census in 1907. As a final measure I employ the average number of newly granted patents between 1902 and 1913. I use the Baten/Streb patents database. ${ }^{91}$ The database includes all patents granted between 1877 and 1918 by the German patent office that were economically valuable, indicated by the lifespan of a patent. Since patent

\footnotetext{
${ }^{87}$ The available data only allows using expected instead of actual tax revenues. However, since these were reported on an annual basis it can be supposed that expected tax revenues would have been adjusted if previous expectations had not been met. Hence, they provide a good approximation of actual tax revenues.

${ }^{88}$ Eheberg, 'Steuer', pp. 124-6.

${ }^{89}$ Tax revenues are a proxy for GDP commonly used in the literature.

${ }^{90}$ Note that due to the lack of data, it is not possible to use the same kind of economic measures to estimate the impact of the Gewerbeschule and Realschule.

${ }^{91}$ See Streb et al., 'Technological and geographical knowledge spillover'.
} 
holders had to pay annual renewal fees to maintain the patent, Streb et al. argue that a patentee would only do so if patenting provided economic benefits. ${ }^{92}$

\section{IV.}

As Figures A1 to A4 show, Gewerbeschulen and Realschulen were opened in most instances in big, prosperous, and economically developed counties; this is especially true in case of the Gewerbeschule: the three largest Bavarian cities in population in 1840 - Munich, Landau (Bav. Palatinate), and Nuremberg - all opened a Gewerbeschule..$^{93}$ After all, it was the Bavarian King Ludwig I himself who demanded the opening of a Gewerbeschule in all big cities. ${ }^{94}$ In case of the Realschule, Figure A3 implies a weaker relationship between economic development and population of a county and the opening of a Realschule by 1878 . However, the difference in population between counties opening and not opening one in 1871 is still positive and significant on the $1 \%$-level. ${ }^{95}$ According to the summary statistics given by Table A2, counties introducing modern secondary education were not only bigger in terms of population but also more likely to be administrational independent, making them a higher class of Bavarian cities. Furthermore, they housed a higher share of Protestants and military and counted more advocacy groups. In case of the Gewerbeschule this is not surprising since these schools were founded in cooperation with local trade and industrial associations, as outlined in section II It can be supposed that existence of these lobby groups is closely linked to economic prosperity of the respective region.

Therefore, the introduction of modern secondary education was presumably driven by endogenous factors (such as population size $\mathrm{e}^{96}$ and economic prosperity). Any OLS estimation not accounting for this endogeneity will lead to biased and inconsistent estimates. Here, endogeneity is likely to arise from two sources: reverse causality and omitted variables.

\footnotetext{
${ }^{92}$ Ibid., pp. 349-50. See also Streb et al., 'Knowledge spill-over', Richter and Streb, 'Catching-up', and Cinirella and Streb, 'Role of human capital'.

${ }^{93}$ Gewerbeschulen were opened in counties with an average population of 35,965.88 vs. 18,023.33 in counties that not opened a Gewerbeschule by 1835 . Thus, the difference between these two groups yielded by two-sample T-test amounts to $17,942.55$ people and is significant on the $1 \%$-level.

${ }^{94}$ Döllinger, Sammlung, p. 1691.

95 The difference in average population obtained by a two-sample T-test is -20,001.96, implying that counties with a Realschule in 1878 were on average significantly bigger in 1871 than counties without one (46,454.63 vs. 26,452.66).

${ }^{96}$ In fact, population size, population density, and urbanization are frequently used in the literature as proxies for economic development. See for example Acemoglu et al., 'Reversal of fortune'.
} 
Reverse causality would imply that especially prosperous counties or cities opened a Gewerbeschule and/or later a Realschule. This is in line with Diebolt and Fontvieille who argue that in case of Germany and France, human capital investments prior to 1945 were a response to economic growth. $^{97}$

Omitted variables could comprise for example economic spirit. Counties with a population with a high interest in the economy would be more likely to have a business or industrial associations lobbying for their interests and hence more likely to adopt this new school type.

Consequently, the adopted econometric specification in section III is not necessarily able to determine a causal relationship between economic performance and the introduction of the Gewerbeschule. However, it implicates that there exists a positive correlation between these two variables.

An alternative econometric specification that can be adopted to estimate the economic effect of modern secondary education is propensity score matching as proposed by Rosenbaum and Rubin. ${ }^{98}$ Propensity score matching uses observational characteristics to estimate the probability of treatment in terms of the propensity score (which is strictly between 0 and 1). Individuals are then matched according to their propensity scores and treatment effects can be estimated by comparing alike individuals - based on observable characteristics - with and without treatment. This approach enables estimation of treatment effects if treatment is not assigned randomly.

In case of the Gewerbeschule and Realschule this means that additional county characteristics prior to 'treatment' - i.e. opening of these schools - are needed. These characteristics - comprising for example city size, measures reflecting economic development, religion, number and type of existing schools, universities, public health sector, local business and industrial associations, etcetera - help to predict the opening of a Gewerbeschule and/or Realschule. By accounting for these additional variables it is possible to circumvent the endogeneity associated with introduction of these schools and hence estimate a consistent effect on economic outcomes - under the assumption that these observables solely determine the endogeneity.

\footnotetext{
${ }^{97}$ See Diebolt and Fontvieille, 'Dynamic forces'. According to North and Thomas, education is not a cause of economic growth, it is growth itself (North and Thomas, Rise of the western world, p. 2).

${ }^{98}$ See Rosenbaum and Rubin, 'Propensity score'.
} 
I use several variables to predict the introduction of modern secondary education. ${ }^{99}$ In case of the introduction of a Gewerbeschule by 1835 , these are population structure in 1840 (including share of children, religious affiliations, and stationed military), administrational independence in 1830, geography (dummy variable for Bavarian Palatinate), advocacy groups for education and economy in 1839, economic development in 1840 (proxied by employment structure), and financial development in 1835 (proxied by the existence of a savings bank). Characteristics predicting the opening of a Realschule by 1896 include population structure in 1871 (religious affiliations and stationed military), administrational independence in 1871, geography (dummy variable for Bavarian Palatinate), advocacy groups for education, economy and science in 1872, economic development in 1871 (proxied by number of self-employed in trade and industry), and other existing schools in 1871 (Lateinschule and Gymnasium).

Propensity scores are then calculated using probit regressions based on respective county characteristics. Table A3 and A4 in the Appendix list for each county the respective propensity scores for the introduction of the Gewerbeschule by 1835 and Realschule by 1896 .

According to Table A3, the majority of counties have a relatively low probability of opening a Gewerbeschule. Except for Freising (which opened one despite having a low propensity score), Eichstaett and Germersheim (which both did not open one despite having a high propensity score), the sample is divided into two kinds of counties: those with low propensity scores and no Gewerbeschule and those with high propensity scores and a Gewerbeschule. Thus, the calculated propensity scores confirm the apprehension of section III implying that the introduction of a Gewerbeschule was driven by endogenous factors. ${ }^{100}$

Propensity scores for the introduction of the Realschule in Table A4 are less divided between treated and non-treated counties: four counties with a propensity score less than 0.1 (i.e. Weilheim, Neumarkt, Kronach, and Wasserburg) opened a Realschule, whereas two counties with a score above 0.8 (i.e. Dillingen and Schwabach) did not open one. This implicates that introduction of a Realschule

\footnotetext{
${ }^{99}$ Note that due to data availability, I have to use data that were in some instances collected some years after introduction of these schools.

${ }^{100}$ Probit regression used to predict the introduction of a Gewerbeschule implicates that administrational independence and advocacy groups lobbying for education played a significant (positive) role in deciding whether a county opened this school or not.
} 
did not entirely depend on observable economic characteristics, which may be endogenous to the outcome considered. Thus, the introduction of the Realschule exhibits a higher degree of randomness than the introduction of the Gewerbeschule.

Figures 3 to 6 display corresponding histograms of the frequency distribution of the propensity scores for treated and control groups.

Figure 3

Figure 4

Figure 5

Figure 6

According to Figures 3 and 4, there exists a considerable lack of overlap between the control and treatment group in the Gewerbeschule sample. In case of the Realschule, Figures 5 and 6 indicate some - albeit very low - degree of overlap.

Hence, conducting traditional propensity score matching using matching methods does not seem feasible in this case. ${ }^{101}$ Crump et al. suggest restricting samples with clear lack of overlap of propensity scores between treated and control groups from 0.1 to $0.9 .^{102}$ In case of the Gewerbeschule, the number of observations would shrink to a mere 14 (6 treated). Therefore, I restrict the Gewerbeschule sample to counties with corresponding propensity scores between 0.01 and 0.9 . The resulting sample then comprises 34 observations, with 7 of them treated (corresponding to all framed counties in Table A3). In case of the Realschule, I follow Crump et al. and restrict the sample to observations with corresponding propensity scores between 0.1 and 0.9 . This yields a sample with 53 counties, with 20 of them treated (corresponding to all framed counties in Table A4). ${ }^{103}$

\footnotetext{
${ }^{101}$ In case of the Gewerbeschule and Realschule, propensity score matching still yields 6 balanced blocks indicating that there is no difference in controls and propensity scores between treated and control variables. However, the size of blocks differs from only 2 to 94 (Gewerbeschule) and 7 to 90 (Realschule) observations.

${ }^{102}$ See Crump et al., 'Dealing with limited overlap'.

${ }^{103}$ Note that three observations (i.e. Hemau, Velburg, and Heilsbronn) will not be used in the subsequent empirical analyses due to the lack of data resulting from local government reorganizations. In $1880 \mathrm{Hemau}$ and Velburg were merged to one county, i.e. Parsberg (Volkert, Handbuch, p. 546) and Heilsbronn was dissolved (Ibid., p. 480). All three counties are used in the calculation of propensity scores but are disregarded from subsequent regressions estimating economic effects after 1880.
} 


\section{V.}

The economic impact of the introduction of a Gewerbeschule in a county is presented by Table 8 . In the first row, results for Panel A, i.e. an OLS regression without any control variables, are shown. The correlation of the Gewerbeschule with all dependent variables - except for the population share of people employed in services - is significant on the $1 \%$ level or $5 \%$ level: introduction of the Gewerbeschule by 1835 is associated with a higher share of the population self-employed in trade and industry in 1871 (columns 1 and 2), a higher share of the population working in services and industry in 1882 (columns 4 and 5), more expected tax revenues (column 3), and a higher average number of business registrations per capita 1869-1875 (column 6). Panel B includes geography (i.e. a dummy variable for counties in the Bavarian Palatinate), infrastructure (i.e. a dummy variable for administrational independence in 1871), and population structure in 1871 (columns 1, 2 and 6) and 1880 (columns 3, 4, and 5). Except for the coefficients on self-employed and business registrations, results stay significant. More variables controlling for Gymnasien in 1862 and advocacy groups in 1872 are added in Panel C. Hence, Panel C controls for the widest range of socio-economic factors in fact potential endogenous factors themselves - in Table 8 and in all following regressions. Even if this wide set of controls is accounted for, the Gewerbeschule stays positively and significantly correlated with the share of population employed in services and industry as well as with tax revenues. This suggests that counties with a Gewerbeschule since 1835 are associated with a 0.8 and 3 percentage point higher share of the population employed in services and industry, respectively, and with 3 Marks more expected tax revenues per capita. However, these results are likely to be biased by endogeneity problems. I will deal with this problem below.

\section{Table 8}

Table 9 reports the estimated impact of the Realschule obtained by OLS. The table follows the same structure as Table 8: Panel A includes no controls, Panel B adds geography (i.e. a dummy variable for Bavarian Palatinate), administrational independence in 1896 and population structure in 1905, and Panel C once again controls for the other type of secondary schooling, i.e. the Gymnasium (1906), as well as for advocacy groups in 1872 lobbying for science, education and economy, and the 
share of self-employed in trade and industry in 1871. First-row estimates of Panel A are once again positive and significant in almost all cases. For example, counties which opened a Realschule by 1896 are associated on average with 1.8 more businesses in trade per 1,000 inhabitants, a 1.43 and 4.96 percentage point higher share of the population employed in trade and industry, respectively, and 0.008 more patents per 1,000 inhabitants than counties without a Realschule. Significance and magnitude are hardly affected if population structure, advocacy groups and other factors are controlled for: estimates in Panel B and C stay in most cases significant. Hence, counties that introduced a Realschule between 1877 and 1896 are significantly associated with a higher population share employed in trade and industry and a higher yearly number of new patents some ten to thirty years later, even when controlling for the widest range of socio-economic factors. This finding is in line with the hypothesis that modern secondary education is associated with an industrialized workforce and higher innovativeness proxied by patent grants.

\section{Table 9}

However, as outlined in section IV, simple OLS regressions based on the whole sample of counties may not be reliable since the opening of a modern secondary school in a county was probably driven by endogenous factors. This implies that any estimation based on the whole sample is comparing completely different kinds of counties. Thus, the following analysis approaches this problem by sample restriction via propensity scores.

OLS results based on restricted samples as outlined in section IV are given in Table 10 for the Gewerbeschule and Table 11 for the Realschule. Note that these tables present economic effects of modern secondary education for comparable counties - based on propensity scores. Consequently, counties differ substantially only in terms of having opened a Gewerbeschule and/or Realschule or not.

\section{Table 10}

Results of Panel A in Table 10 are once again positive and significant in columns 4 and 5: counties that opened a Gewerbeschule in 1835 are associated with a higher share of the population employed in industry in 1882, more tax revenues per capita between 1881 and 1884, and a higher 
number of net registrations per 1,000 inhabitants between 1869 and 1875 than comparable counties without such a school. Estimates in Panel B and C which are successively controlling for more (potentially endogenous) variables, are in most cases statistically insignificant; only the share of population working in industrial professions is significantly and positively associated with having a Gewerbeschule. This supports the hypothesis that the presence of a Gewerbeschule led to a higher share of the population working in the industrial sector.

Table 11 presents the estimates of the economic effect of having opened a Realschule by 1896 based on comparable counties. Results obtained by this selected sample confirm previous findings: counties with a Realschule are significantly associated with a higher population share employed in trade and industry even when controlling for a wide range of socioeconomic factors. Furthermore, the Realschule is once again associated with a higher degree of innovativeness several years later - as captured by patents grants. Results are even more significant than those obtained by the whole sample.

\section{Table 11}

As outlined in section IV, I restrict the samples based on propensity scores following Crump et al. who propose a sample restriction from 0.1 to $0.9 .{ }^{104}$ In case of the Gewerbeschule I depart from this approach since this restriction would shrink the sample size to only 14 observations. However, I use this cutoff as a robustness check for the results obtained for the restricted sample of the Gewerbeschule above.

Table 12 reports the results of this further restricted sample consisting of 6 with and 8 counties without a Gewerbeschule. Note that this sample includes only 14 observations. Since the inclusion of control variables would substantially reduce the degrees of freedom, only results obtained by Panel A are shown.

The positive significant effect of the Gewerbeschule on the share of population employed in industry as well as on tax revenues is confirmed. However, the effect on people working in services and business registrations in Panel A is no longer significant. Since the estimates do not change much in magnitude, this results mainly from increasing standard errors due to the smaller sample size.

Table 12

\footnotetext{
${ }^{104}$ See Crump et al., 'Dealing with limited overlap'.
} 
Hence, this robustness check further confirms the obtained positive effects of the introduction of the Gewerbeschule in 1835 on the share of population employed in industry some fifty years later.

All in all, comparing alike counties with and without modern secondary education confirms previous results obtained for the full sample: the effect of modern secondary education on innovations and the share of people employed in industry and trade is highly significant. Hence, counties that introduced this new type of school increased their economic performance in the following years.

\section{VI.}

This paper analyzes the role of secondary education in economic development, thereby focusing on innovations taking place in the Bavarian schooling system during the nineteenth century. The introduction of the Gewerbeschule in 1829 and the Realschule in 1877 provide a unique opportunity to study this question in a historical context: polytechnic advocacy groups and the mercantile middle class lobbied for the introduction of these schools claiming that the Gymnasium could not offer an education preparing for commercial and industrial occupations. The Gewerbeschule, and later the Realschule, were supposed to meet this demand by offering scientific-technical as well as general education.

Since the curricula of these schools focused on subjects training commercial and industrial skills, the empirical analysis employs county-level data on business formations and people employed in trade and industry as well as the number of newly granted patents. Counties with are then compared to counties without modern secondary education in respect to these outcome measures capturing economic performance. Results obtained by OLS indicate that the opening of a Gewerbeschule in a county by 1835 is significantly associated with a higher population share employed in services and industry in 1882 and more expected tax revenues between 1881 and 1884. In case of the Realschule, school counties are significantly associated with a higher number of new patents per capita between 1902 and 1913 as well as a higher population share employed in industry and trade in 1907. Using propensity score matching to deal with the underlying endogeneity of a school opening confirms these results: modern secondary education is associated with a higher share of the population employed in industry and trade, a higher level of innovativeness several years after introduction and more tax 
revenues per capita. These results are robust to including a wide range of control variables. Hence, these findings indicate that graduates indeed chose industrial and trade related careers justifying empirically Kleinfeller's perception. Counties opening modern secondary education therefore forged ahead in economic terms.

This finding highlights the importance of education for economic development. Even though it is not possible to determine the exact channel through which modern secondary education might have influenced economic outcomes due to data limitations ${ }^{105}$, the empirical analysis reveals that there exists a link between economic performance of a county and the presence of a modern secondary school. Since nineteenth century Bavaria was still mainly an agrarian state, secondary education promoting industrial, commercial and scientific knowledge might have not only influenced economic outcomes directly but may have also provided the basis needed to catch up to technologically advanced Prussia.

Besides effects on the economy, modern secondary education might as well affect social mobility. As the Gymnasium understood itself as an institution for the elite, the introduction of the Gewerbeschule and Realschule might have encouraged other social classes to also participate in secondary schooling.

Related to the issue of social mobility is whether modern secondary education increased private returns of schooling. As Kleinfeller argues, graduates were highly valued by the local business environment. In addition, education obtained at the Realschule/Gewerbeschule enabled former students to reach advanced occupational positions more easily. ${ }^{106}$ As Goldin and Goldin and Katz show for the United States, private returns to secondary education were substantial at the beginning of the twentieth century: these amounted to 11 percent for males. ${ }^{107}$ Moreover, a High School degree enabled graduates to find employment in profitable, well-paid white collar jobs. Since the American High School with its emphasis on general academic as well as on vocational, commercial, technical,

\footnotetext{
${ }^{105}$ For instance, it could well be that the presence of a modern secondary school itself attracted companies if these believed in the superior technical and commercial skills of graduates. Then the share of people working in industrial and trade professions would increase due to the higher supply of jobs in these sectors.

${ }^{106}$ Kleinfeller, Realschulen, pp. 101-4.

${ }^{107}$ See Goldin, 'America's graduation' and Goldin and Katz, 'Education and income'.
} 
and industrial courses and its self-imposed aim 'to prepare students for life, rather than for college'108 bore more resemblance to the Bavarian Gewerbeschule/Realschule than to the Gymnasium ${ }^{109}$, returns to Bavarian modern secondary education might have been substantial as well.

Therefore, the impact of modern secondary education on social mobility as well as on private returns of education provides an interesting field for future research.

\footnotetext{
${ }^{108}$ Goldin, ‘America’s graduation', p. 352.

${ }^{109}$ In fact, the American secondary schooling system in form of the High School underwent a substantial reform comparable to the Bavarian system imposed by the introduction of the Gewerbeschule. Around 1900 most secondary schools still taught a classical curriculum preparing students for college/university. Like in Bavaria, this school program was conceived as elitist and critics claimed that this education could not meet the demands imposed by the American industry. The curriculum was gradually reformed and courses such as chemistry, shorthand, and accounting were added to the curriculum on the cost of Latin, Greek, and rhetoric. See Goldin, 'Egalitarianism'. An important difference between the American and Bavarian secondary schooling system was that the American High School was open to both genders.
} 


\section{Footnote references}

Acemoglu, D., Johnson, S. and Robinson, J. A. 'Reversal of fortune: geography and institutions in the making of the modern world income distribution', Quarterly Journal of Economics 117, no. 4 (2002), pp. 1231-94.

Albisetti, J. 'The debate on secondary school reform in France and Germany', in D. K. Müller, F. Ringer and B. Simon eds., The Rise of the Modern Educational System: Structural Change and Social Reproduction 1870-1920, (Cambridge, 1989), pp. 182-96.

Barro, R. J. 'Economic growth in a cross section of countries', Quarterly Journal of Economics 106, no. 2 (1991), pp. 407-43. . 'Human capital and growth', American Economic Review 91, no. 2 (2001), pp. 12-7.

Becker, G. S., Human capital (New York, 1964).

Becker, S. O., Hornung, E. and Woessmann, L. 'Education and catch-up in the industrial revolution', American Economic Journal: Macroeconomics 3, no. 3 (2011), pp. 92-126.

Becker, S. O. and Woessmann, L. 'Was Weber wrong? A human capital theory of Protestant economic history', Quarterly Journal of Economics 124, no. 2 (2009), pp. 531-96.

Behrman, J. R. and Birdsall, N. 'The quality of schooling: quantity alone is misleading', American Economic Review 73, no. 5 (1983), pp. 928-46.

Benhabib, J. and Spiegel, M. M. 'The role of human capital in economic development: evidence from aggregate cross-country data', Journal of Monetary economics 34, no. 2 (1994), pp. 143-73.

Bennell, P. 'General versus vocational secondary education in developing countries: a review of the rates of return evidence', Journal of Development Studies 33, no. 2 (1996), pp. 230-47.

Buchinger, H., Die Geschichte der bayerischen Realschule: Die Entwicklung der bayerischen Realschule von ihren Anfängen bis zur Errichtung der Oberrealschule im Jahre 1907 (Passau, 1983).

Cinnirella, F. and Streb, J. 'The role of human capital and innovation in Prussian economic development', CESifo Working Paper Series, no. 4391 (2013).

Crump, R. K., Hotz, V. J., Imbens, G. W. and Mitnik, O. A. 'Dealing with limited overlap in estimation of average treatment effects', Biometrika 96, no. 1 (2009), pp. 187-99.

Diebolt, C. and Fontvieille, L. 'Dynamic forces in educational development: a long-run comparative view of France and Germany in the 19th and 20th centuries', Compare: A Journal of Comparative and International Education 31, no. 3 (2001), pp. 295-309.

Diesel, E., Diesel: Der Mensch, das Werk, das Schicksal (München, 1983).

Döllinger, G. F., Sammlung der im Gebiete der inneren Staats-Verwaltung des Königreichs Bayern bestehenden Verordnungen: aus amtlichen Quellen geschöpft und systematisch geordnet. 9,3 Unterricht und Bildung (München, 1838).

Easterlin, R. A. 'Why isn't the whole world developed?', Journal of Economic History 41, no. 1 (1981), pp. 1-19.

Eheberg, K. Th., 'Steuer', in J. Conrad, L. Elster, W. Lexis and E. Loening eds., Handbuch der Staatswissenschaften 6, (Jena, 1894), pp. 83-137.

Fuller, B., Edwards, J. H. Y. and Gorman, K. 'When does education boost economic growth? School expansion and school quality in Mexico', Sociology of Education 59, no. 3 (1986), pp. 167-81.

Goldin, C. 'America's graduation from high school: the evolution and spread of secondary schooling in the twentieth century', Journal of Economic History 58, no. 2 (1998), pp. 345-74.

. 'Egalitarianism and the returns to education during the great transformation of education in America', Journal of Political Economy 107, no. S6 (1999), pp. S65-S94. 
Goldin, C. and Katz, L. F. 'Education and income in the early twentieth century: evidence from the Prairies', Journal of Economic History 60, no. 3 (2000), pp. 782-818.

Hamann, B., Geschichte des Schulwesens: Werden und Wandel der Schule im ideen- und sozialgeschichtlichen Zusammenhang (Heilbronn, 1993).

Hanushek, E. A. and Kimko, D. D. 'Schooling, labor-force quality, and the growth of nations', American Economic Review 90, no. 5 (2000), pp. 1184-1208.

Hecker, A. J., Kurzer Abriß über die Geschichte der Königlichen Real-Schule in den ersten fünfzig Jahren nach ihrer Stiftung (Berlin, 1797).

Inkster, I., Science and technology in history: an approach to industrial development (London, 1991).

Jeismann, K. E. 'Schule. Hochschule: Das höhere Knabenwesen', in K. E. Jeismann and P. Lundgreen eds., Handbuch der deutschen Bildungsgeschichte, (München, 1987), pp. $152-80$

Keyser, E., Deutsches Städtebuch: Städtebuch Rheinland-Pfalz. 5 vols (Stuttgart, 1964).

- Deutsches Städtebuch: Bayerisches Städtebuch 1. 5 vols (Stuttgart, 1971).

- Deutsches Städtebuch: Bayerisches Städtebuch 2. 5 vols (Stuttgart, 1974).

Kleinfeller, A., Die Realschulen in Bayern und ihre Gegner: Ein Versuch zur Verständigung über die Realschulfrage (München, 1883).

Kraus, H. C., Kultur, Bildung und Wissenschaft im 19. Jahrhundert (München, 2008).

Krueger, A. B. and Lindahl, M. 'Education for growth: why and for whom?', Journal of Economic Literature 39, no. 4 (2001), pp. 1101-36.

Luther, K. 'Heinrich von Buz', in R. A. Müller ed., Unternehmer - Arbeitnehmer: Lebensbilder aus der Frühzeit der Industrialisierung in Bayern, (München, 1987a), pp. 133-7.

—. 'Rudolf Diesel', in R. A. Müller ed., Unternehmer - Arbeitnehmer: Lebensbilder aus der Frühzeit der Industrialisierung in Bayern, (München, 1987b), pp. 143-52.

Mankiw, N. G., Romer, D. and Weil, D. N. 'A contribution to the empirics of economic growth', Quarterly Journal of Economics 107, no. 2 (1992), pp. 407-37.

Meer, U. 'Friedrich Fischer', in R. A. Müller ed., Unternehmer - Arbeitnehmer: Lebensbilder aus der Frühzeit der Industrialisierung in Bayern, (München, 1987), pp. 237-42.

Mitch, D. 'The role of education and skill in the British industrial revolution', in J. Mokyr ed., The British industrial revolution: an economic perspective, (Boulder, 2008), pp. 241-79.

Musson, A. E. and Robinson, E., Science and technology in the industrial revolution (Manchester, 1969).

Nelson, R. R. and Phelps, E. S. 'Investment in humans, technological diffusion, and economic growth', American Economic Review 56, no. 1/2 (1966), pp. 69-75.

North, D. C. and Thomas, R. P., The rise of the western world: a new economic history (Cambridge, 1973).

Psacharopoulos, G. 'To vocationalize or not to vocationalize? That is the curriculum question', International Review of Education 33, no. 2 (1987), pp. 187-211.

Psacharopoulos, G. and Patrinos, H. A. 'Returns to investment in education: a further update', Education Economics 12, no. 2 (2004), pp. 111-34.

Punke, H. H. 'Recent developments in German secondary education. I', School Review 38, no. 8 (1930a), pp. 576-84.

. 'Recent developments in German secondary education. II', School Review 38, no. 9 (1930b), pp. 680-93.

Richter, R. and Streb, J. 'Catching-up and falling behind: knowledge spillover from American to German machine toolmakers', Journal of Economic History 71, no. 4 (2011), pp. 1006-31.

Ringer, F. K. 'Higher education in Germany in the nineteenth century', Journal of Contemporary History 2, no. 3 (1967), pp. 123-38. 
Ringer, F. K., Education and society in modern Europe (Bloomington, 1979).

Romer, P. M. 'Endogenous technological change', Journal of Political Economy 98, no. 5 (1990), pp. S71-S102.

Rosenbaum, P. R. and Rubin, D. B. 'The central role of the propensity score in observational studies for causal effects', Biometrika 70, no. 1 (1983), pp. 41-55.

Schultz, T. W. 'Investment in human capital', American Economic Review 51, no. 1 (1961), pp. 1-17.

Solow, R. M. 'A contribution to the theory of economic growth', Quarterly Journal of Economics 70, no. 1 (1956), pp. 65-94.

Streb, J., Baten, J. and Yin, S. 'Technological and geographical knowledge spillover in the German empire 1877-1918', Economic History Review 59, no. 2 (2006), pp. 347-73.

Streb, J., Wallusch, J. and Yin, S. 'Knowledge spill-over from new to old industries: The case of German synthetic dyes and textiles (1878-1913)', Explorations in Economic History 44, no. 2 (2007), pp. 203-23.

Volkert, W., Handbuch der bayerischen Ämter, Gemeinden und Gerichte 1799-1980 (München, 1983).

Walters, P. B. and Rubinson, R. 'Educational expansion and economic output in the United States, 1890-1969: a production function analysis', American Sociological Review 48, no. 4 (1983), pp. 480-93.

\section{Official publications}

Ministerialblätter für Kirchen- und Schul-Angelegenheiten im Königreiche Bayern, various years.

Regierungsblätter für das Königreich Bayern, various years.

Beiträge zur Statistik des Königreichs Bayerns (BSKB):

Bevölkerung. (1850): I

Anstalten für Wissenschaft, Kunst, Unterricht und Erziehung nach dem Stande von 1851/52 und früherer Jahre. (1855): V

Anstalten für Wissenschaft, Kunst, Unterricht und Erziehung im Königreiche Bayern nach dem Stande von 1862/63 nebst Angaben über dieselben aus früheren Jahren. (1866): XIV

Statistik der bayerischen Sparkassen. (1873): XXVI

Statistik des Unterrichts im Königreiche Bayern für die Jahre 1869/70, 1870/71 und 1871/72 mit Rückblicken auf die Ergebnisse früherer Jahre. (1873): XXVII: 1, 2

Ergebnisse der Volkszählung im Königreiche Bayern vom 1. Dezember 1871 nach einzelnen Gemeinden (Gemeinde-Verzeichniss). (1873): XXVIII

Statistik der Vereine für Bildungszwecke in Bayern nach dem Stande des Jahres 1872. (1874): $\mathrm{XXX}$

Die bayerische Bevölkerung nach Berufs- und Erwerbsklassen: Ergebnisse der Volkszählung vom 1. Dezember 1871. (1885): XXXIIII

Die Bayerische Bevölkerung nach Geschlecht, Alter und Civilstand sowie nach der Gebürtigkeit: Ergebnisse der Volkszählung vom 1. Dezember 1880: (1883). XXXXVI

Die Ergebnisse der Berufszählung im Königreich Bayern vom 05. Juni 1882. I. Theil: Die bayerische Bevölkerung nach ihrer Berufsthätigkeit. (1885): XXXXVIII

Die Ergebnisse der Berufszählung im Königreich Bayern vom 05. Juni 1882. III. Theil: Die bayerische Bevölkerung nach ihrer gewerblichen Thätigkeit. (1886): L

Die Ergebnisse der Unterrichts-Statistik im Königreich Bayern für das Schuljahr 1884/85. (1887): LII

Die Gemeinde-Umlagen im Königreich Bayern in den Jahren 1882-1886. (1889): LV 
Gemeinde-Verzeichnis für das Königreich Bayern nach den endgültigen Ergebnissen der Volkszählung vom 1. Dezember 1905. (1906): LXVIII

Gemeinde-Verzeichnis für das Königreich Bayern nach den endgültigen Ergebnissen der Volkszählung vom 1. Dezember 1905. (1906): LXVIII

Gewerbe und Handel in Bayern: Nach der Betriebszählung vom 12. Juni 1907. (1911): LXXXII

Beiträge zur Statistik Bayerns (BSB):

Historisches Gemeindeverzeichnis: Die Einwohnerzahlen der Gemeinden Bayerns in der Zeit von 1840 bis 1952. (1953): 192

Zeitschrift des Königlich Bayerischen Statistischen Bureau (ZKBSB):

Die Bewegung der Gewerbe in Bayern im Jahre 1868 bis 1878. (1880): 12

Die Hauptergebnisse der Unterrichtsstatistik im Königreich Bayern für das Schuljahr 1885/86. (1888): 20

Die Hauptergebnisse der Unterrichtsstatistik im Königreich Bayern für das Schuljahr 1892/93. (1894): 26

Die Hauptergebnisse der Unterrichtsstatistik im Königreich Bayern für das Schuljahr 1903/1904. (1906): 38

Beiträge zur Statistik der Gemeindebesteuerung in Bayern. (1883): 15 
Table 1

Curriculum of the Gewerbeschule 1833-64

\begin{tabular}{lccc}
\hline \multirow{2}{*}{ Subject } & \multicolumn{3}{c}{ Grade } \\
\cline { 2 - 4 } & $\mathbf{1}$ & $\mathbf{2}$ & $\mathbf{3}$ \\
\hline \hline Arithmetic/Algebra & 6 & 6 & 6 \\
Planimetry & 6 & - & - \\
Stereometry & - & 6 & - \\
Descriptive Geometry & - & - & 6 \\
Graphics & 6 & 12 & 12 \\
Natural History & 6 & 3 & - \\
Physical Science & - & 3 & - \\
Chemistry & - & - & 6 \\
$\begin{array}{l}\text { Encyclopedia of } \\
\text { Industry }\end{array}$ & 3 & 3 & 3 \\
Accounting & - & - & 3 \\
\hline $\begin{array}{l}\text { Notes: adapted from Buchinger, Geschichte der Realschule, pp. } \\
\text { 123-4. } \\
\text { Source: Döllinger, Sammlung, pp. 1519-20. }\end{array}$ &
\end{tabular}

Table 2 Curriculum of the 'Realienunterricht' for the students of the Gewerbeschule at the Gymnasium

\begin{tabular}{lccc}
\hline \multirow{2}{*}{ Subject } & \multicolumn{3}{c}{ Grade } \\
\cline { 2 - 4 } & $\mathbf{1}$ & $\mathbf{2}$ & $\mathbf{3}$ \\
\hline \hline Religion & 6 & 4 & 4 \\
$\begin{array}{l}\text { History and } \\
\text { Geography }\end{array}$ & 4 & 6 & 6 \\
German Grammar & 4 & - & - \\
Rhetoric & - & 4 & 4 \\
French ${ }^{\mathrm{a}}$ & 4 & 4 & 4 \\
\hline $\begin{array}{l}\text { Notes: adapted from Buchinger, Geschichte der Realschule, p. } \\
\text { 124. } \\
\text { Source: Döllinger, Sammlung, p. 1523. } \\
\text { a voluntary }\end{array}$ & &
\end{tabular}


Table 3 Curriculum of the reformed Gewerbeschule 1864-76

\begin{tabular}{|c|c|c|c|}
\hline \multirow{2}{*}{ Subject } & \multicolumn{3}{|c|}{ Grade } \\
\hline & 1 & 2 & 3 \\
\hline Religion & 2 & 2 & 2 \\
\hline German & 5 & 4 & 3 \\
\hline Geography & 2 & 2 & - \\
\hline History & 2 & 2 & 2 \\
\hline Arithmetic & 5 & - & - \\
\hline Natural History & 4 & - & - \\
\hline Physical Science & - & 4 & - \\
\hline Chemistry & - & - & 6 \\
\hline \multicolumn{4}{|c|}{ Additional courses for students of the industrial department } \\
\hline Algebra & - & 2 & 3 \\
\hline Plane Geometry & - & 4 & - \\
\hline Descriptive Geometry & - & - & 2 \\
\hline Graphics & 8 & 8 & 6 \\
\hline Mechanics & - & - & 4 \\
\hline French & 2 & 2 & 2 \\
\hline \multicolumn{4}{|c|}{ Additional courses for students of the commercial department } \\
\hline Commercial Arithmetic & - & 5 & - \\
\hline Commerce & - & 6 & 6 \\
\hline Commercial Geography \& History & - & - & 3 \\
\hline French & 5 & 5 & 5 \\
\hline English & - & - & 5 \\
\hline Calligraphy & 5 & - & - \\
\hline \multicolumn{4}{|c|}{ Additional courses for students of the agricultural department } \\
\hline Agriculture & 6 & 6 & 8 \\
\hline Arithmetic Exercises & - & 2 & - \\
\hline Geometry & - & - & 3 \\
\hline Graphics & 4 & 2 & 2 \\
\hline
\end{tabular}

Source: Regierungsblatt (1864), pp. 546-70. 
Table 4

Curricula of the Realschule 1877

\begin{tabular}{lcccccc}
\hline \multirow{2}{*}{ Subject } & \multicolumn{6}{c}{ Grade } \\
\cline { 2 - 7 } & $\mathbf{1}$ & $\mathbf{2}$ & $\mathbf{3}$ & $\mathbf{4}$ & $\mathbf{5}$ & $\mathbf{6}$ \\
\hline \hline Religion & 2 & 2 & 2 & 2 & 2 & 2 \\
German & 6 & 6 & 4 & 4 & 3 & 3 \\
French & 6 & 6 & 5 & 5 & 3 & 3 \\
English & - & - & - & - & 5 & 5 \\
Geography & 2 & 2 & 2 & 2 & 1 & 1 \\
History & - & - & 2 & 2 & 2 & 2 \\
Arithmetic & 5 & 4 & 4 & 2 & 1 & 1 \\
Mathematics & - & - & - & 6 & 6 & 6 \\
Description of Nature & - & 3 & 3 & - & - & - \\
Physics & - & - & - & 2 & 2 & 2 \\
Chemistry/Mineralogy & - & - & - & - & 3 & 3 \\
Calligraphy & 3 & 2 & 2 & - & - & - \\
Graphics & 3 & 3 & 4 & 4 & 4 & 4 \\
Physical Education & 2 & 2 & 2 & 2 & 2 & 2 \\
\hline Hours per Week & 29 & 30 & 30 & 31 & 34 & 34 \\
\hline Notes: adapted from Ministerialblatt (1877), p. 224. & & & &
\end{tabular}

Table 5

Curricula of the Lateinschule and Gymnasium 1874

\begin{tabular}{|c|c|c|c|c|c|c|c|c|c|}
\hline \multirow{2}{*}{ Subject } & \multicolumn{5}{|c|}{ Lateinschule } & \multicolumn{4}{|c|}{ Gymnasium } \\
\hline & 1 & 2 & 3 & 4 & 5 & I & II & III & IV \\
\hline Religion & 2 & 2 & 2 & 2 & 2 & 2 & 2 & 1 & 1 \\
\hline German & 6 & 3 & 3 & 2 & 2 & 2 & 2 & 3 & 3 \\
\hline Latin & 7 & 10 & 10 & 8 & 8 & 8 & 8 & 7 & 7 \\
\hline Greek & - & - & - & 6 & 6 & 6 & 6 & 6 & 6 \\
\hline French & - & - & - & - & - & 2 & 2 & 2 & 2 \\
\hline History & - & - & 2 & 2 & 2 & 2 & 2 & 3 & 3 \\
\hline Geography & 2 & 2 & 2 & 2 & 2 & - & - & - & - \\
\hline Arithmetic, Mathematics and Physics & 3 & 3 & 3 & 2 & 4 & 4 & 4 & 4 & 4 \\
\hline Calligraphy & 3 & 3 & 2 & 1 & - & - & - & - & - \\
\hline Physical Education & 2 & 2 & 2 & 2 & 2 & 2 & 2 & 2 & 2 \\
\hline Hours per Week & 25 & 25 & 26 & 27 & 28 & 28 & 28 & 28 & 28 \\
\hline
\end{tabular}

Notes: adapted from Ministerialblatt (1874), p. 329.

Hebrew, English, Italian and stenography were offered as optional subjects in the Gymnasium. Graphics, music and singing were offered as optional subjects in the Lateinschule and Gymnasium. See Ministerialblatt (1874), p. 329. 
Table 6 Intended careers of graduates at the Realschule Munich

\begin{tabular}{ccccc}
\hline Year & $\begin{array}{c}\text { Number } \\
\text { of } \\
\text { Graduates }\end{array}$ & $\begin{array}{c}\text { Trade, } \\
\text { Commerce } \\
\text { \& Industry }\end{array}$ & $\begin{array}{c}\text { Middle- } \\
\text { level } \\
\text { Civil } \\
\text { Servants }\end{array}$ & Study \\
\hline \hline 1878 & 37 & 8 & 7 & 22 \\
1879 & 41 & 11 & 11 & 19 \\
1880 & 45 & 21 & 15 & 9 \\
1881 & 42 & 25 & 5 & 12 \\
1882 & 47 & 23 & 10 & 14 \\
1883 & 48 & 33 & 4 & 11 \\
\hline
\end{tabular}

Notes: adapted from Buchinger, Geschichte der Realschule, p. 172

Source: Kleinfeller, Realschulen, pp. 24-5.

Table 7

Number of students at secondary schools

\begin{tabular}{ccc|cc}
\hline \multirow{4}{*}{ Year } & \multicolumn{2}{c}{ Gewerbeschule/Realschule } & \multicolumn{2}{c}{ Gymnasium } \\
\cline { 2 - 5 } & $\begin{array}{c}\text { Students (per } \\
1,000 \text { people) }\end{array}$ & Schools & $\begin{array}{c}\text { Students (per } \\
1,000 \\
\text { people) }\end{array}$ & Schools \\
\hline \hline $1834 / 35$ & $1,450(0.33)$ & 28 & $2,334(0.53)$ & 25 \\
$1841 / 42$ & $1,105(0.25)$ & 24 & $/$ & $/$ \\
$1851 / 52$ & $2,549(0.56)$ & 26 & $3,529(0.77)$ & 28 \\
$1862 / 63$ & $3,539(0.75)$ & 29 & $2,508(0.53)$ & 28 \\
$1871 / 72$ & $3,745(0.78)$ & 36 & $2,640(0.55)$ & 28 \\
$1876 / 77^{\mathrm{a}}$ & $5,375(1.07)$ & 40 & $/$ & $/$ \\
$1877 / 78^{\mathrm{b}}$ & $7,685(1.53)$ & 40 & $/$ & $/$ \\
$1885 / 86$ & $8,451(1.56)$ & 46 & $14,120(2.60)$ & 33 \\
$1894 / 95$ & $13,278(2.28)$ & 51 & $17,039(2.93)$ & 37 \\
$1906 / 07$ & $14,031(2.15)$ & 55 & $19,475(2.98)$ & 45 \\
\hline
\end{tabular}

Notes: Number in brackets indicates students per 1,000 people (total Bavarian population) in $1840,1852,1861,1871,1875,1880,1885,1895$, and 1905.

${ }^{\text {a }}$ Last year of the Gewerbeschule.

${ }^{\mathrm{b}}$ First year of the Realschule.

Sources: BSKB, I (1850); BSKB, V (1855), pp. 10-11, 26-7; BSKB, XIV (1866), pp. 9-13;

BSKB, XXVII (1873), pp 68-9, 196-7; Ministerialblatt (1877), p. 114, 473; Ministerialblat (1886), pp. 278-9; Ministerialblatt (1895), pp. 9-11; Ministerialblatt (1907), pp. 14-6; ZKBSB, 20 (1888), pp. 38-9; Buchinger, Geschichte der Realschule, p. 145; BSB, 192 (1953), pp.10-11. 


\begin{tabular}{|c|c|c|c|c|c|c|}
\hline \multirow{3}{*}{ Dependent Variable: } & \multicolumn{2}{|c|}{$\begin{array}{l}\% \text { of self-employed in total } \\
\text { population }(1871) \text { in }\end{array}$} & \multirow{3}{*}{$\begin{array}{l}\text { Expected tax } \\
\text { revenues per } \\
\text { capita (1881-4) } \\
\text { (3) }\end{array}$} & \multicolumn{2}{|c|}{$\begin{array}{l}\% \text { of population employed } \\
(1882) \text { in }\end{array}$} & \multirow{3}{*}{$\begin{array}{c}\text { Business } \\
\text { registrations } \\
\text { per } 1,000 \\
\text { inhabitants } \\
(1869-75) \\
(6)\end{array}$} \\
\hline & Trade & Industry & & Services & Industry & \\
\hline & (1) & (2) & & (4) & (5) & \\
\hline \multicolumn{7}{|l|}{ Panel A: no controls } \\
\hline \multirow[t]{2}{*}{ Gewerbeschule by 1835} & $0.475 * * *$ & $1.195 * *$ & $1.655 * * *$ & $1.782 * * *$ & $4.284 * * *$ & $0.278 * *$ \\
\hline & {$[0.119]$} & {$[0.556]$} & {$[0.509]$} & {$[0.329]$} & {$[0.932]$} & {$[0.136]$} \\
\hline \multicolumn{7}{|c|}{ Panel B: small set of controls } \\
\hline \multirow[t]{2}{*}{ Gewerbeschule by 1835} & 0.371 & 1.938 & $2.442 *$ & $0.716^{*}$ & $2.356 * * *$ & 0.022 \\
\hline & {$[0.263]$} & {$[1.170]$} & {$[1.426]$} & {$[0.375]$} & {$[0.891]$} & {$[0.131]$} \\
\hline \multicolumn{7}{|c|}{ Panel C: large set of controls } \\
\hline \multirow[t]{2}{*}{ Gewerbeschule by 1835} & 0.533 & 2.605 & $3.150 *$ & $0.805 * *$ & $2.917 * *$ & 0.005 \\
\hline & {$[0.372]$} & {$[1.790]$} & {$[1.729]$} & {$[0.320]$} & {$[1.293]$} & {$[0.160]$} \\
\hline Observations & 123 & 123 & 121 & 121 & 121 & 123 \\
\hline
\end{tabular}

Table 9

Economic effect of the Realschule (introduction between 1877 and 1896)

\begin{tabular}{|c|c|c|c|c|c|}
\hline \multirow[t]{2}{*}{ Dependent Variable: } & \multicolumn{2}{|c|}{$\frac{\underline{\text { Number of }}}{\text { businesses per 1,000 }}$} & \multicolumn{2}{|c|}{$\underline{\frac{\% \text { of population }}{\text { employed (1907) in }}}$} & \multirow{2}{*}{$\begin{array}{c}\frac{\text { New patents }}{\text { per } 100,000} \\
\frac{(1902-1913)}{\text { inhabitants }} \\
\text { (5) }\end{array}$} \\
\hline & $\begin{array}{l}\text { Trade } \\
\text { (1) }\end{array}$ & $\begin{array}{l}\text { Industry } \\
\text { (2) }\end{array}$ & $\begin{array}{l}\text { Services } \\
\text { (3) }\end{array}$ & $\begin{array}{c}\text { Industry } \\
\text { (4) }\end{array}$ & \\
\hline \multicolumn{6}{|l|}{ Panel A: no controls } \\
\hline Realschule by 1896 & $\begin{array}{l}1.783^{*} \\
{[0.961]}\end{array}$ & $\begin{array}{l}-2.359 \\
{[2.249]}\end{array}$ & $\begin{array}{c}1.312 * * * \\
{[0.273]}\end{array}$ & $\begin{array}{c}4.595 * * * \\
{[1.129]}\end{array}$ & $\begin{array}{c}0.783 * * * \\
{[0.279]}\end{array}$ \\
\hline \multicolumn{6}{|c|}{ Panel B: small set of controls } \\
\hline Realschule by 1896 & $\begin{array}{l}-0.740 \\
{[1.166]}\end{array}$ & $\begin{array}{l}-2.069 \\
{[2.923]}\end{array}$ & $\begin{array}{c}1.011 * * * \\
{[0.384]}\end{array}$ & $\begin{array}{c}2.801 * * \\
{[1.404]}\end{array}$ & $\begin{array}{c}0.553 * * \\
{[0.225]}\end{array}$ \\
\hline \multicolumn{6}{|c|}{ Panel C: large set of controls } \\
\hline Realschule by 1896 & $\begin{array}{c}-0.601 \\
{[1.157]}\end{array}$ & $\begin{array}{c}-1.958 \\
{[2.720]}\end{array}$ & $\begin{array}{c}0.831 * * \\
{[0.419]}\end{array}$ & $\begin{array}{l}1.981 * \\
{[1.119]}\end{array}$ & $\begin{array}{l}0.400^{*} \\
{[0.216]}\end{array}$ \\
\hline Observations & 146 & 146 & 146 & 146 & 146 \\
\hline
\end{tabular}

Notes: Table reports OLS estimates, weighted by share of population born in municipality (1900). Unit of observation is a county. Robust standard errors are in parantheses: significantly different from 0 at $* * * 1 \%, * * 5 \%$ and $* 10 \%$ level. Panel A includes no controls. Panel B includes geography (Bavarian Palatinate), administrational independence

(1896), and population (i.e. population shares of Catholics, Protestants, Jews, and military) (1905) as controls. Panel C includes geography, administrational independence (1905), population structure (1905), share of self-employed in trade and industry (1871), Gymnasium (1906), and advocacy groups (1872) as controls. 
$\%$ of self-employed in total population (1871) in
Expected tax

revenues per capita (1881-4)
Business registrations per 1,000 inhabitants (1869-75)

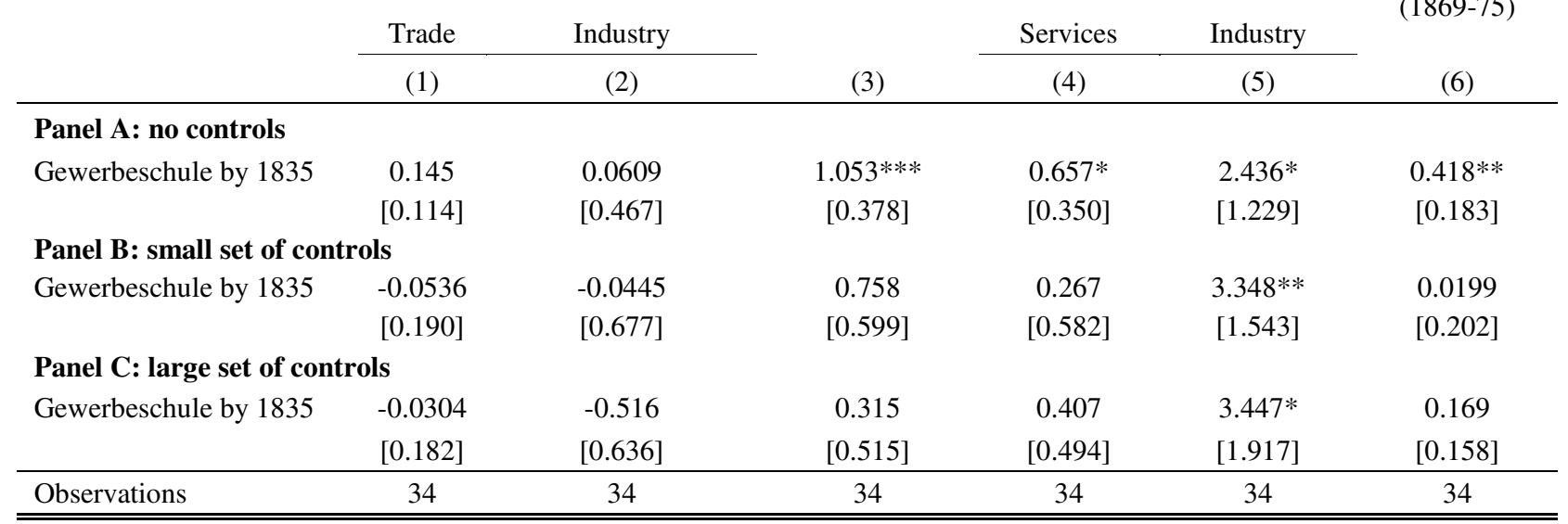

Notes: Table reports OLS estimates, weighted by share of non-immigrants (1862-75) in total population (1871). Unit of observation is a county. Robust standard errors are in parentheses: significantly different from 0 at $* * * 1 \%, * * 5 \%$ and $* 10 \%$ level. Sample includes observations with propensity scores $0.01<$ pscore $<0.9$. Panel A includes no controls. Panel B includes geography (Bavarian Palatine), administrational independence (1871) and population structure (i.e. population shares of Catholics, Protestants, Jews, and military) (1880) as controls. Panel C includes geography, administrational independence (1871), population structure (1880), Gymnasium (1862) and advocacy groups (1872) as controls.

Table 11 Economic effect of the Realschule (introduction between 1877 and 1896), restricted sample

\begin{tabular}{|c|c|c|c|c|c|}
\hline \multirow[t]{2}{*}{ Dependent Variable: } & \multicolumn{2}{|c|}{$\frac{\frac{\text { Number of Businesses }}{\text { per 1,000 Inhabitants }}}{\underline{(1907) \text { in }}}$} & \multicolumn{2}{|c|}{$\underline{\frac{\% \text { of Population }}{\text { employed (1907) in }}}$} & \multirow{2}{*}{$\begin{array}{c}\frac{\text { New Patents }}{\text { per } 100,000} \\
\underline{\text { Inhabitants }} \\
\underline{(1902-1913)} \\
(5)\end{array}$} \\
\hline & $\begin{array}{l}\text { Trade } \\
(1)\end{array}$ & $\begin{array}{c}\text { Industry } \\
\text { (2) }\end{array}$ & $\begin{array}{c}\text { Services } \\
\text { (3) }\end{array}$ & $\begin{array}{c}\text { Industry } \\
(4)\end{array}$ & \\
\hline \multicolumn{6}{|l|}{ Panel A: no controls } \\
\hline Realschule by 1896 & $\begin{array}{c}0.410 \\
{[1.618]}\end{array}$ & $\begin{array}{c}4.783 \\
{[2.976]}\end{array}$ & $\begin{array}{c}0.827 * * \\
{[0.398]}\end{array}$ & $\begin{array}{c}5.120 * * * \\
{[1.65]}\end{array}$ & $\begin{array}{c}0.402 * * * \\
{[0.134]}\end{array}$ \\
\hline \multicolumn{6}{|c|}{ Panel B: small set of controls } \\
\hline Realschule by 1896 & $\begin{array}{c}-1.966 \\
{[1.889]}\end{array}$ & $\begin{array}{c}4.814 \\
{[4.114]}\end{array}$ & $\begin{array}{c}1.050 \\
{[0.628]}\end{array}$ & $\begin{array}{c}5.545^{* *} \\
{[2.081]}\end{array}$ & $\begin{array}{c}0.583 * * * \\
{[0.213]}\end{array}$ \\
\hline \multicolumn{6}{|c|}{ Panel C: large set of controls } \\
\hline Realschule by 1896 & $\begin{array}{c}1.006 \\
{[3.855]} \\
\end{array}$ & $\begin{array}{r}8.549 \\
{[7.712]} \\
\end{array}$ & $\begin{array}{c}1.125 \\
{[0.785]} \\
\end{array}$ & $\begin{array}{l}5.931 * \\
{[3.317]} \\
\end{array}$ & $\begin{array}{c}0.440 * * * \\
{[0.157]} \\
\end{array}$ \\
\hline Observations & 53 & 53 & 53 & 53 & 53 \\
\hline
\end{tabular}

Notes: Table reports OLS estimates, weighted by share of population born in municipality (1900). Unit of observation is county. Robust standard errors are in parentheses: significantly different from 0 at $* * * 1 \%, * * 5 \%$ and $* 10 \%$ level. Sample includes observations with propensity scores $0.1<$ pscore $<0.9$. Panel A includes no controls. Panel B includes geography (Bavarian Palatinate), administrational independence (1896), and population (i.e. population shares of Catholics,

Protestants, Jews, and military) (1905) as controls. Panel C includes geography, administrational independence (1905), population structure (1905), share of self-employed in trade and industry (1871), Gymnasium (1906), Gewerbeschule (1871), and advocacy groups (1872) as controls. 


\begin{tabular}{|c|c|c|c|c|c|c|}
\hline \multirow{3}{*}{ Dependent Variable: } & \multicolumn{2}{|c|}{$\begin{array}{l}\% \text { of self-employed in total } \\
\text { population }(1871) \text { in }\end{array}$} & \multirow{2}{*}{$\begin{array}{l}\text { Expected tax } \\
\text { revenues per } \\
\text { capita }(1881-4)\end{array}$} & \multicolumn{2}{|c|}{$\begin{array}{l}\% \text { of population employed } \\
(1882) \text { in }\end{array}$} & \multirow{3}{*}{$\begin{array}{c}\text { Business } \\
\text { registrations } \\
\text { per } 1,000 \\
\text { inhabitants } \\
(1869-75) \\
(6)\end{array}$} \\
\hline & Trade & Industry & & Services & Industry & \\
\hline & (1) & (2) & (3) & (4) & (5) & \\
\hline \multicolumn{7}{|l|}{ Panel A: no controls } \\
\hline \multirow[t]{2}{*}{ Gewerbeschule by 1835} & -0.075 & -0.117 & $0.942 *$ & 0.534 & $3.103 * *$ & 0.330 \\
\hline & {$[0.195]$} & {$[0.462]$} & {$[0.460]$} & {$[0.478]$} & {$[1.383]$} & {$[0.261]$} \\
\hline Observations & 14 & 14 & 14 & 14 & 14 & 14 \\
\hline
\end{tabular}

Notes: Table reports OLS estimates, weighted by share of non-immigrants (1862-75) in total population (1871). Unit of observation is a county. Robust standard errors are in parentheses: significantly different from 0 at $* * * 1 \%, * * 5 \%$ and $* 10 \%$ level. Sample includes observations with propensity scores $0.1<$ pscore $<0.9$. Panel A includes no controls. 
Figure 1

Bavarian schooling system 1833-76

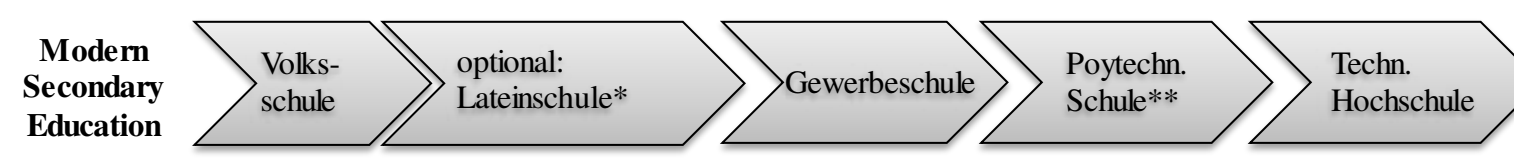

Age $\sum \begin{array}{lllllllllllllll}6 & 7 & 8 & 9 & 10 & 11 & 12 & 13 & 14 & 15 & 16 & 17 & 18 & 19 & \ldots\end{array}$

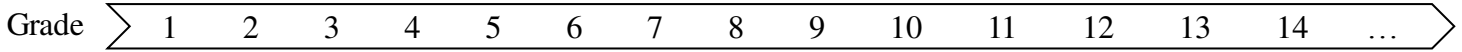

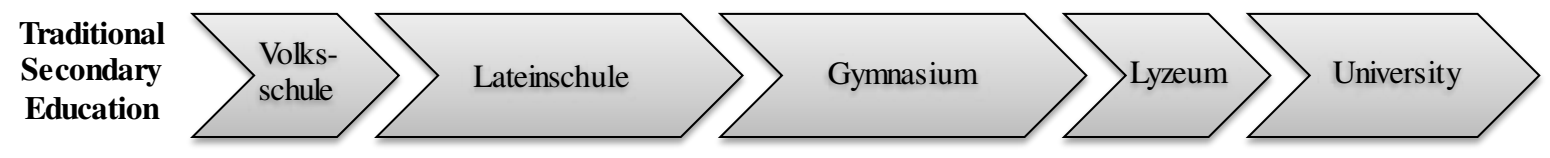

Notes: adapted from Buchinger, Geschichte der Realschule, p. 128

* Children could transfer after the second grade to the Lateinschule; transfer to the Gewerbeschule was possible from both school types.

** Polytechnische Schule was abolished in 1864 and reopened as Industrieschule in 1868. See Buchinger, Geschichte der Realschule, pp. 123-8, and Regierungsblatt (1868), pp. 1698-70.

Sources: Döllinger, Sammlung, pp. 1509-1649; Regierungsblatt (1830), pp. 877-948; Regierungsblatt (1833), pp. 1378-99; Regierungsblatt (1868), pp. 169870 .

Figure $2 \quad$ Bavarian schooling system 1877-1907

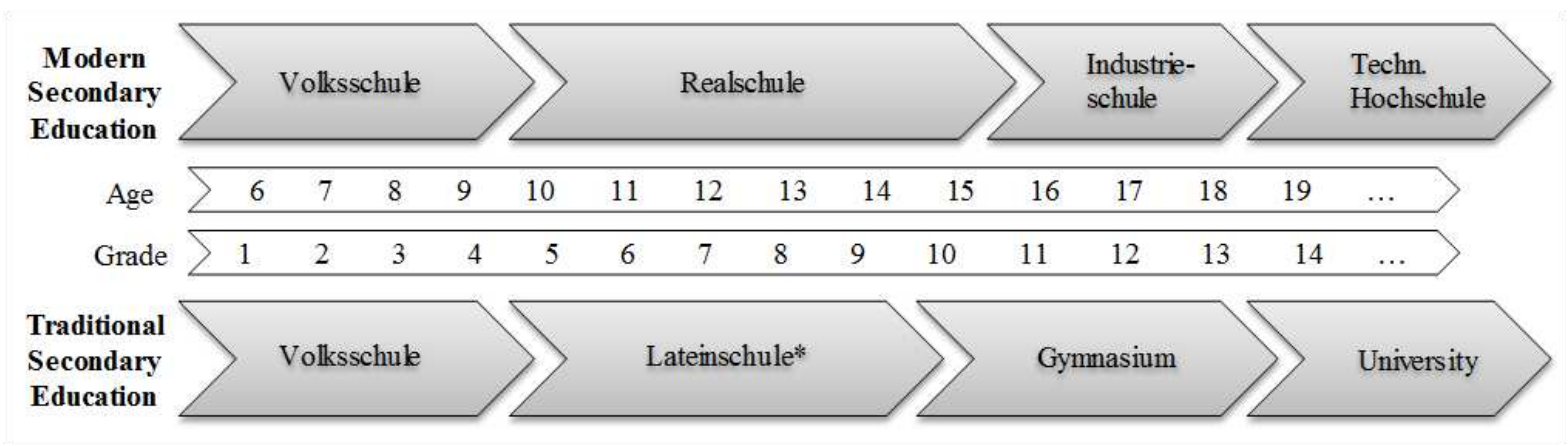

Notes: * Gymnasien were nine-year institutions including the five-year Lateinschulen. In cities without a Gymnasium, Lateinschulen could exist on their own. From 1894 onwards, the first six grades of the Gymnasium were called 'Progymnasium'. Progymnasien existed only in combination with a Gymnasium whereas Lateinschulen also existed in cities without Gymnasien. Lateinschulen comprised up to five classes and prepared for transfer to a Progymnasium (in another city). See Ministerialblatt (1874), pp. 323-62, and Ministerialblatt (1894), pp. 189-95.

Sources: Ministerialblatt (1874), pp. 323-62,; Ministerialblatt (1877), pp. 197-255; Ministerialblatt (1891), pp. 239-86; Ministerialblatt (1894), pp. 189-95, 287323. 
Figure 3 Histogram propensity scores for counties without Gewerbeschule by 1835

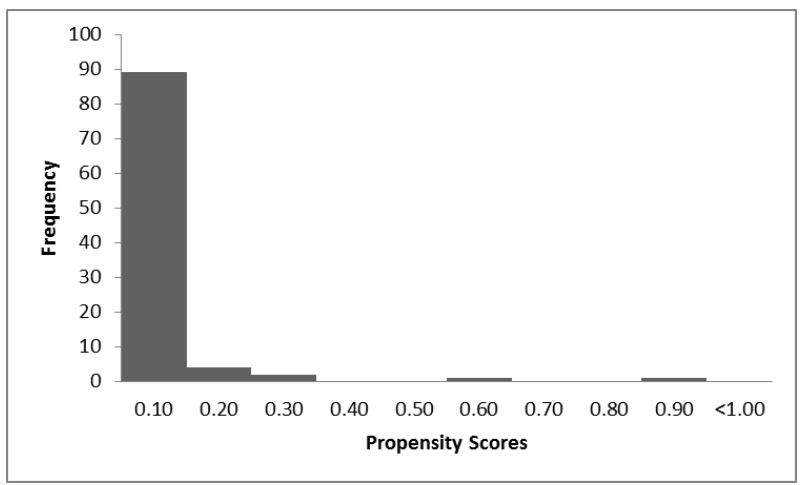

Figure 4 Histogram propensity scores for counties with Gewerbeschule by 1835

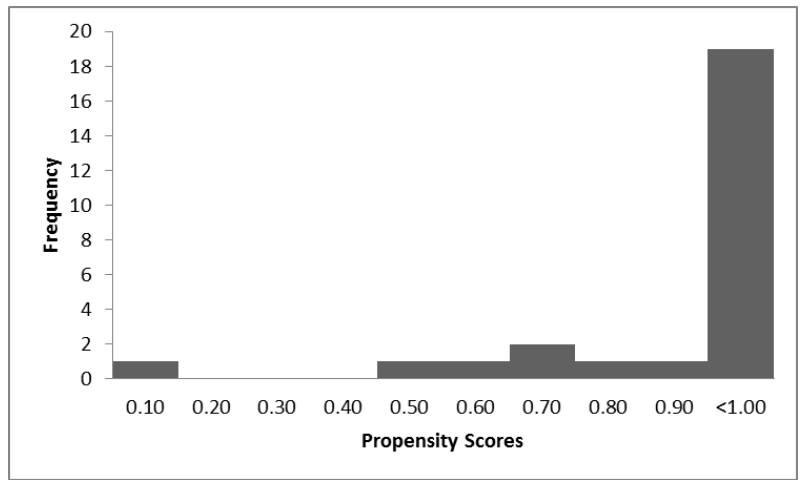

Figure 5 Histogram propensity scores for counties without Realschule by 1896

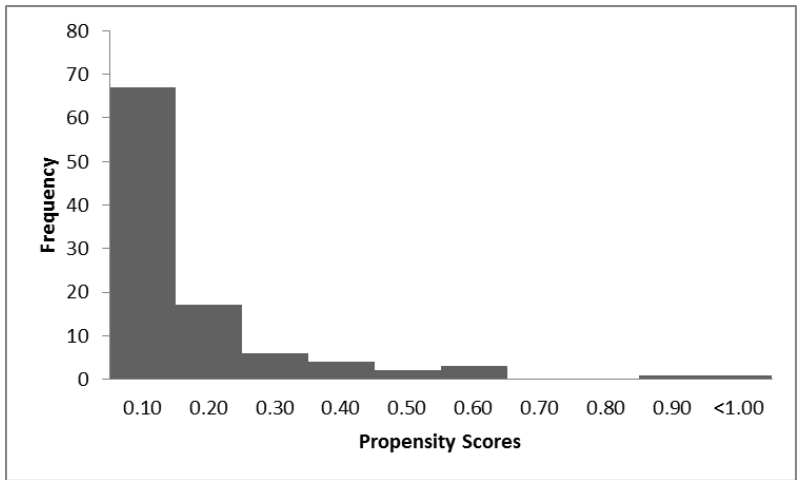

Figure 6 Histogram propensity scores for counties with Realschule by 1896

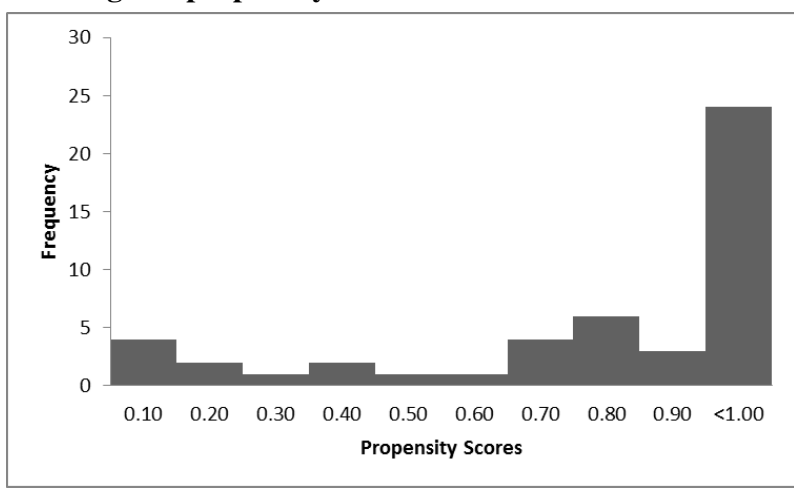




\section{Appendix}

Table A1

Data description and source

\begin{tabular}{l}
\hline Variable \\
\hline \hline Schools \\
Gewerbeschule by 1835 \\
Gewerbeschule in 1871 \\
Gymnasium in 1862,1871 , and \\
1906
\end{tabular}

Realschule in 1878, 1896

County characteristics

Administrational independence

Bavarian Palatinate

Advocacy groups in 1839,1872

Savings bank in 1835

Population in 1840, 1852, 1861, $1871,1880,1895$, and 1905

\section{Economic outcomes}

Business registrations per capita

Share of population self-employed in trade and industry in 1871

Expected tax revenues per capita 1881-4

Share of population employed in services and industry in 1882

Number of trade and industrial businesses per capita in 1907

Granted patents per capita between 1902-13

Description

Source

Binary, 1 if county opened a Gewerbeschule by 1835 indicated by receiving district funds and revenues by funds of former Bürgerschulen

Binary, 1 if county is listed as having a Gewerbeschule

Binary, 1 if county had a Gymnasium and/or

Lateinschule/Progymnasium

Binary 1, if county opened a Realschule by 1896

Binary, 1 if county was administrational independent ('kreisfrei'/'kreisunmittelbar'), i.e. city that fulfills certain governmental functions in is jurisdiction (including a corresponding county) granted by the Bavarian state government

Binary, 1 if county was located in the Bavarian Palatinate

Number of advocacy groups. Three categories: science, education and economy.

Binary, 1 if county had a savings bank

Population of a county and respective per-capita numbers of Catholics, Protestants and Jews

(1906) 1896)
Döllinger, Sammlung.

BSKB, XXVII: 1, 2

BSKB, XIV (1866);

BSKB, XXVII: 1, 2

(1873), Ministerialblatt

Ministerialblatt (1877,

Keyser, Bayerisches Städtebuch 1; idem, Bayerisches Städtebuch 2; idem, Städtebuch Rheinland-Pfalz; Volkert, Handbuch.

Keyser, Rheinland-Pfalz; Volkert, Handbuch.

BSKB, XXX (1874)

BSKB, XXVI (1873)

BSKB, XXVIII (1873);

BSKB, XXXXVI (1883);

BSKB, LXVIII (1906)

BSB, 192 (1953)

ZKBSB, 12 (1880)

Average number of new trade businesses per yea obtained by taking the average difference between the number of registrations and closures within one year in one county ("Handelsgewerbebewegung") between 1869 and 1877 (1903-1906) divided by total population in $1871(1905)$

Number of people self-employed in trade or industry in 1871 divided by total population in 1871

Average value of expected tax revenues in Mark between 1881 and 1884 divided by total population 1880

Number of people employed in services or industry in 1882 divided by total population in 1880

Number of trade or industrial businesses in 1907 divided by total population in 1905

Average number of newly granted patents that were economically valuable (indicated by lifespan of patent) between 1902 and 1913 divided by total population in 1905
BSKB, XXXIIII (1885)

ZKBSB, 15 (1883);

BSKB, LV (1889)

BSKB, L (1886)

BSKB, LXXXII (1911)

Baten/Streb Patents

Database. See Streb et al., 'Technological and geographical knowledge spillover'. 


\section{Figure A1 Gewerbeschulen in 1835}

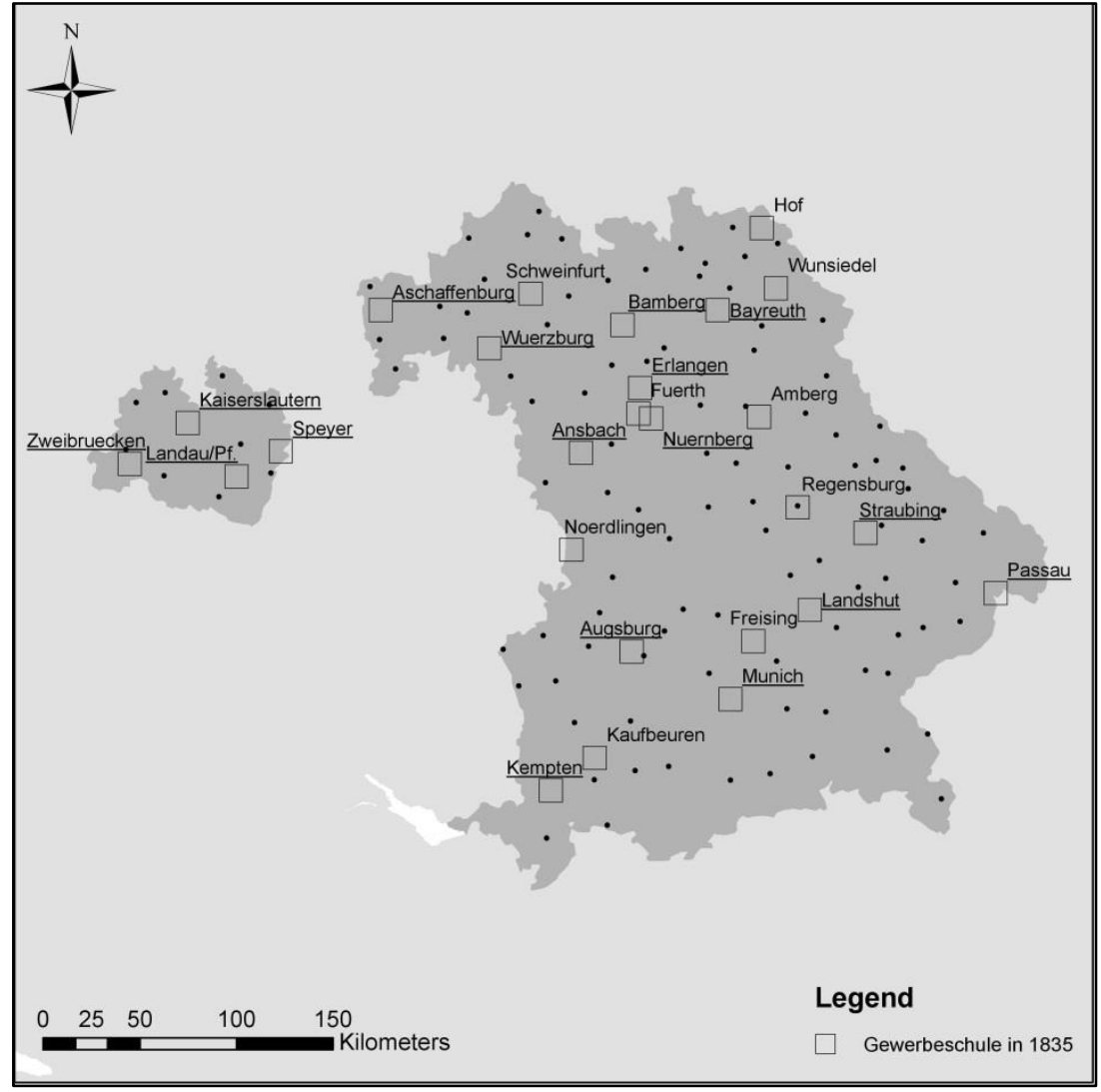

Notes: Counties with a Gewerbeschule in 1835 are indicated by a square. Population exceeds 25,000 in 1840 if county name is underlined. Counties in the control group are indicated by a dot (without a name).

$$
\text { Figure A2 }
$$
Gewerbeschulen in 1871

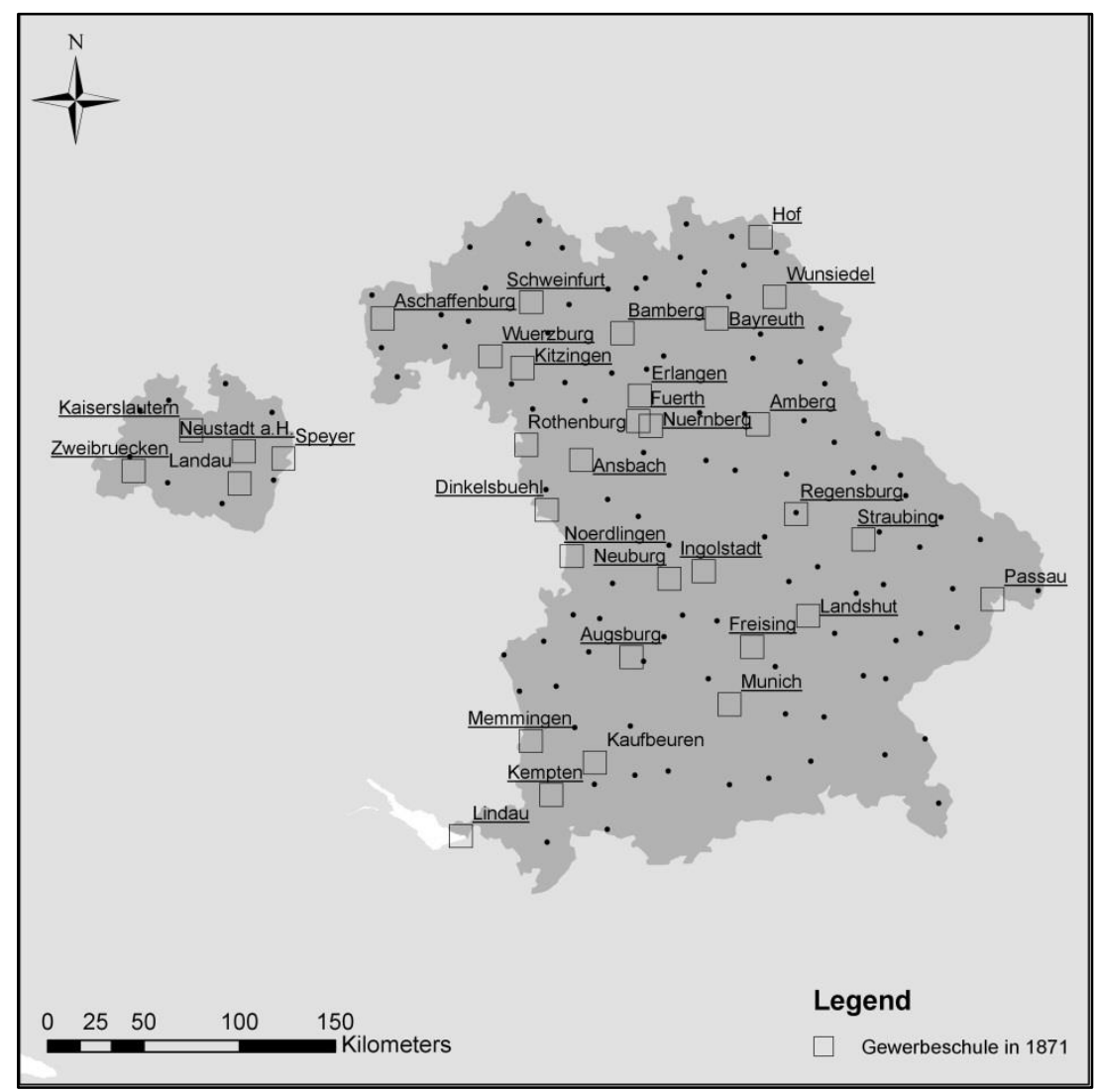

Notes: Counties with a Gewerbeschule in 1871 are indicated by a square. Population exceeds 25,000 in 1871 if county name is underlined. Counties in the control group are indicated by a dot (without a name). 


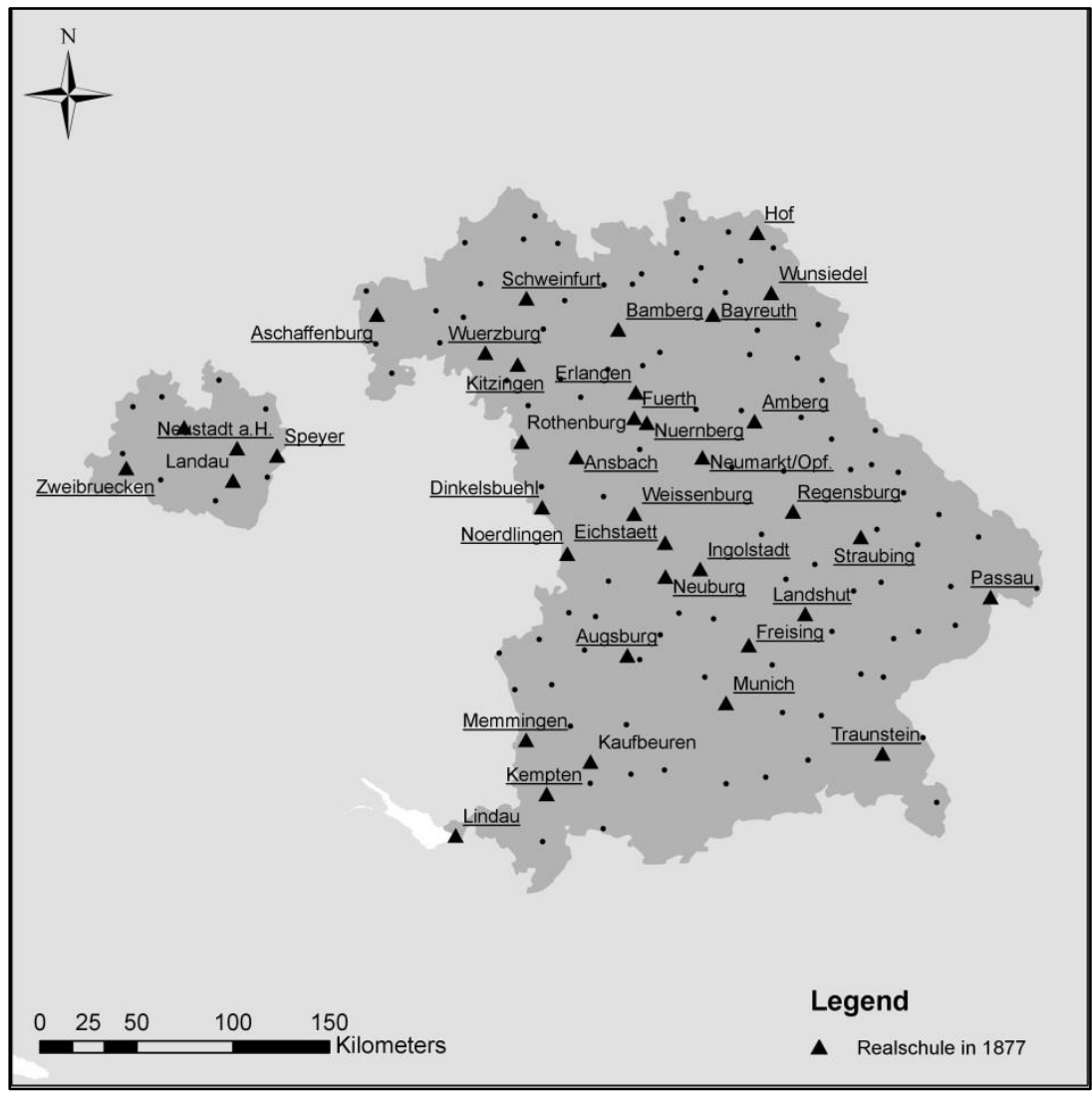

Notes: Counties with a Realschule in 1877 are indicated by a triangle. Population exceeds 25,000 in 1871 if county name is underlined. Counties in the control group are indicated by a dot (without a name).

Figure A4

$$
\text { Realschulen in } 1896
$$

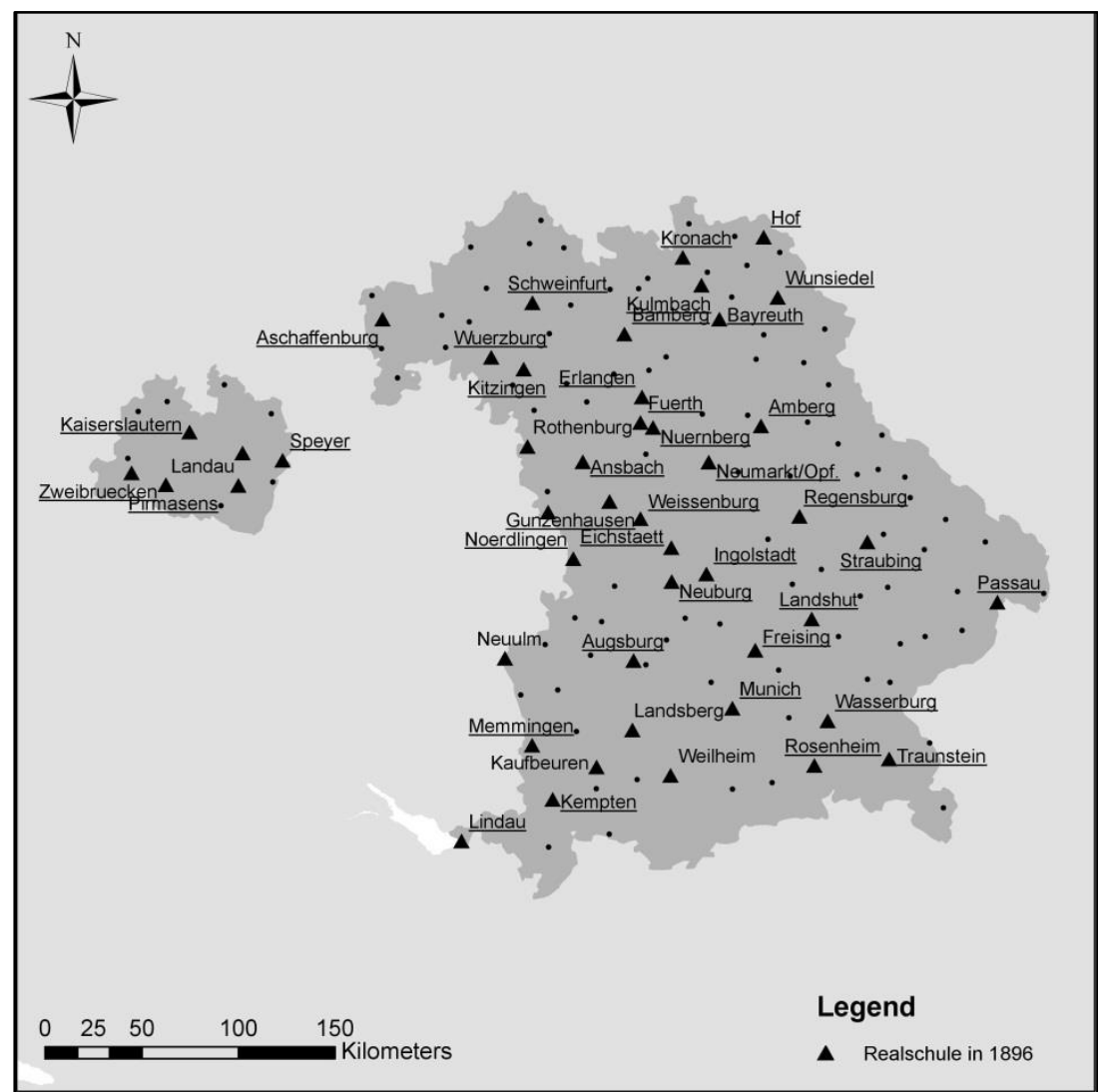

Notes: Counties with a Realschule in 1896 are indicated by a triangle. Population exceeds 25,000 in 1871 if county name is underlined. Counties in the control group are indicated by a dot (without a name). 


\begin{tabular}{|c|c|c|c|c|c|c|c|c|c|c|}
\hline \multirow[b]{3}{*}{ Variable } & \multirow[b]{3}{*}{ Obs. } & \multirow[b]{3}{*}{ Mean } & \multirow[b]{3}{*}{ Std. Dev. } & \multirow[b]{3}{*}{ Min } & \multirow[b]{3}{*}{ Max } & \multicolumn{4}{|c|}{ Counties by Treatment Status } & \multirow[b]{3}{*}{ t-stat } \\
\hline & & & & & & \multicolumn{2}{|c|}{ No Modern Sec. School } & \multicolumn{2}{|c|}{ Modern Sec. School } & \\
\hline & & & & & & Mean & Std. Dev. & Mean & Std. Dev. & \\
\hline \multicolumn{11}{|l|}{ Gewerbeschule Sample } \\
\hline \multicolumn{11}{|l|}{ Schools } \\
\hline Gewerbeschule by 1835 & 123 & 0.2114 & 0.4100 & 0 & 1 & 0 & 0 & 1 & 0 & . \\
\hline Gymnasium in 1862 & 123 & 0.1707 & 0.3778 & 0 & 1 & 0.0103 & 0.1015 & 0.7692 & 0.4297 & -15.97 \\
\hline \multicolumn{11}{|l|}{ County characteristics } \\
\hline Administrational independence in 1830 & 123 & 0.1707 & 0.3778 & 0 & 1 & 0.0103 & 0.1015 & 0.7692 & 0.4297 & -15.97 \\
\hline Administrational independence in 1871 & 123 & 0.2033 & 0.4041 & 0 & 1 & 0.0412 & 0.1999 & 0.8077 & 0.4019 & -13.61 \\
\hline Bavarian Palatinate & 123 & 0.0894 & 0.2865 & 0 & 1 & 0.0722 & 0.2601 & 0.1538 & 0.3679 & -1.29 \\
\hline Advocacy group science in 1839 & 123 & 0.1220 & 0.4166 & 0 & 2 & 0.0103 & 0.1015 & 0.5385 & 0.7606 & -6.69 \\
\hline Advocacy group education youth in 1839 & 123 & 0.1220 & 0.3752 & 0 & 2 & 0.0206 & 0.1428 & 0.5000 & 0.6481 & -6.76 \\
\hline Advocacy group economy in 1839 & 123 & 0.5772 & 0.7997 & 0 & 5 & 0.4948 & 0.6312 & 0.8846 & 1.2108 & -2.24 \\
\hline Savings bank in 1835 & 123 & 0.2764 & 0.4491 & 0 & 1 & 0.1649 & 0.3731 & 0.6923 & 0.4707 & -6.04 \\
\hline Population in 1840 & 123 & 21816 & 14275 & 4709 & 115073 & 18023 & 8036 & 35966 & 21963 & -6.61 \\
\hline Share of military in total population in 1840 & 123 & 0.0108 & 0.0268 & 0 & 0.1217 & 0.0018 & 0.0090 & 0.0443 & 0.0412 & -9.48 \\
\hline Share of Catholics in total population in 1840 & 123 & 0.7307 & 0.3425 & 0.0049 & 1 & 0.7832 & 0.3262 & 0.5346 & 0.3365 & 3.43 \\
\hline Share of Lutherans in total population in 1840 & 123 & 0.2372 & 0.3302 & 0 & 0.9950 & 0.1946 & 0.3135 & 0.3963 & 0.3481 & -2.85 \\
\hline Share of kids in total population in 1840 & 123 & 0.2780 & 0.0379 & 0.1444 & 0.3704 & 0.2809 & 0.0357 & 0.2673 & 0.0442 & 1.63 \\
\hline Share of population dependent on industry in 1840 & 123 & 0.2596 & 0.1415 & 0.0118 & 0.9740 & 0.2259 & 0.1072 & 0.3855 & 0.1806 & -5.74 \\
\hline Share of population dependent on rents in 1840 & 123 & 0.0535 & 0.0655 & 0.0010 & 0.6170 & 0.0392 & 0.0217 & 0.1069 & 0.1241 & -5.14 \\
\hline Advocacy group science in 1872 & 123 & 0.5447 & 1.7238 & 0 & 12 & 0.0619 & 0.2421 & 2.3462 & 3.1615 & -7.12 \\
\hline Advocacy group education youth in 1872 & 123 & 0.6016 & 1.1646 & 0 & 7 & 0.2990 & 0.6152 & 1.7308 & 1.8667 & -6.42 \\
\hline Advocacy group economy in 1872 & 123 & 4.4390 & 5.5532 & 1 & 50 & 3.5361 & 3.2309 & 7.8077 & 9.7694 & -3.66 \\
\hline Population in 1871 & 123 & 33900 & 24183 & 12982 & 239393 & 27782 & 8757 & 56721 & 43273 & -6.19 \\
\hline Share of military in total population in 1871 & 123 & 0.0077 & 0.0083 & 0.0015 & 0.0488 & 0.0055 & 0.0059 & 0.0159 & 0.0107 & -6.58 \\
\hline Share of Catholics in total population in 1871 & 123 & 0.7359 & 0.3300 & 0.0136 & 0.9971 & 0.7701 & 0.3131 & 0.6081 & 0.3650 & 2.26 \\
\hline Share of Lutherans in total population in 1871 & 123 & 0.2374 & 0.3199 & 0.0002 & 0.9802 & 0.2045 & 0.3016 & 0.3602 & 0.3605 & -2.24 \\
\hline Share of Jews in total population in 1871 & 123 & 0.0089 & 0.0118 & 0 & 0.0681 & 0.0080 & 0.0107 & 0.0125 & 0.0152 & -1.74 \\
\hline Population in 1880 & 121 & 37323 & 30630 & 13776 & 301494 & 28922 & 9002 & 68019 & 54319 & -6.75 \\
\hline Share of military in total population in 1880 & 121 & 0.0052 & 0.0110 & 0.0000 & 0.0818 & 0.0029 & 0.0103 & 0.0135 & 0.0098 & -4.70 \\
\hline Share of Catholics in total population in 1880 & 121 & 0.7540 & 0.3218 & 0.0176 & 0.9992 & 0.7952 & 0.3008 & 0.6034 & 0.3560 & 2.77 \\
\hline Share of Lutherans in total population in 1880 & 121 & 0.2367 & 0.3175 & 0.0007 & 0.9820 & 0.1974 & 0.2979 & 0.3803 & 0.3505 & -2.67 \\
\hline Share of Jews in total population in 1880 & 121 & 0.0083 & 0.0109 & 0 & 0.0598 & 0.0068 & 0.0094 & 0.0136 & 0.0142 & -2.93 \\
\hline \multicolumn{11}{|l|}{ Economic outcomes } \\
\hline Share of population self-employed in trade in 1871 & 123 & 0.0094 & 0.0042 & 0.0024 & 0.0346 & 0.0084 & 0.0029 & 0.0132 & 0.0060 & -5.79 \\
\hline Share of population self-employed in industry in 1871 & 123 & 0.0518 & 0.0200 & 0.0157 & 0.1754 & 0.0493 & 0.0170 & 0.0613 & 0.0271 & -2.78 \\
\hline Expected tax revenues per capita $1881-4$ & 121 & 4.1690 & 1.6350 & 1.0441 & 15.216 & 3.8121 & 1.0368 & 5.4732 & 2.5565 & -5.03 \\
\hline Share of population employed in industry in 1882 & 121 & 0.1063 & 0.0400 & 0.0410 & 0.2482 & 0.0970 & 0.0331 & 0.1402 & 0.0453 & -5.42 \\
\hline Share of population employed in services in 1882 & 121 & 0.0000 & 0.0000 & 0.0000 & 0.0000 & 0.0000 & 0.0000 & 0.0000 & 0.0000 & 1.27 \\
\hline Business registrations per 1,000 inhabitants $1869-75$ & 123 & 0.7392 & 0.6411 & -0.3644 & 3.4488 & 0.6804 & 0.6395 & 0.9584 & 0.6098 & -1.99 \\
\hline
\end{tabular}

\section{Realschule Sample}

Schools

Realschule by 1896

Gymnasium in 1871

Gymnasium in 1906

County characteristics

Administrational independence in 1871

Administrational independence in 1896

Administrational independence in 1905

Bavarian Palatinate

Advocacy group science in 1872

Advocacy group education youth in 1872

Advocacy group economy in 1872

Population in 1871

Share of military in total population in 1871

Share of Catholics in total population in 1871

Share of Lutherans in total population in 1871

Share of Jews in total population in 1871

Share of population self-employed in trade in 1871

Share of population self-employed in industry in 1871

Population in 1905

Share of military in total population in 1905

Share of Catholics in total population in 1905

Share of Protestants in total population in 1895

Share of Jews in total population in 1895

Economic outcomes

Trade businesses per capita in 1907

Industrial businesses per capita in 1907

Share of population employed in trade in 1907

Share of population employed in industry in 1907

Newly granted patents per 1,000 inhabitants 1902-13

$\begin{array}{lll}149 & 0.3221 & 0.4689 \\ 149 & 0.3960 & 0.4907 \\ 146 & 0.3425 & 0.4762 \\ & & \\ 149 & 0.2282 & 0.4211 \\ 149 & 0.2752 & 0.4481 \\ 149 & 0.2752 & 0.4481 \\ 149 & 0.0872 & 0.2832 \\ 149 & 0.5101 & 1.5965 \\ 149 & 0.5705 & 1.1405 \\ 149 & 4.1275 & 5.1390 \\ 149 & 32896 & 22622 \\ 149 & 0.0084 & 0.0133 \\ 149 & 0.7237 & 0.3276 \\ 149 & 0.2552 & 0.3249 \\ 149 & 0.0088 & 0.0117 \\ 149 & 0.0092 & 0.0034 \\ 149 & 0.0513 & 0.0164 \\ 146 & 44164 & 55729 \\ 146 & 0.0060 & 0.0152 \\ 146 & 0.7416 & 0.3129 \\ 146 & 0.2488 & 0.3101 \\ 146 & 0.0061 & 0.0078 \\ & & \\ 146 & 0.0283 & 0.0056 \\ 146 & 0.0471 & 0.0138 \\ 146 & 0.0409 & 0.0175 \\ 146 & 0.1279 & 0.0634 \\ 146 & 0.0037 & 0.0123\end{array}$

\begin{tabular}{|c|c|}
\hline 0 & 1 \\
\hline 0 & 1 \\
\hline 0 & 1 \\
\hline 0 & 1 \\
\hline 0 & 1 \\
\hline 0 & 1 \\
\hline 0 & 1 \\
\hline 0 & 12 \\
\hline 0 & 7 \\
\hline 1 & 50 \\
\hline 9905 & 239393 \\
\hline 0.0014 & 0.1351 \\
\hline 0.0136 & 0.9971 \\
\hline 0.0002 & 0.9802 \\
\hline 0 & 0.0681 \\
\hline 0.0036 & 0.0221 \\
\hline 0.0262 & 0.1348 \\
\hline 13017 & 584841 \\
\hline 0 & 0.1056 \\
\hline 0.0227 & 0.9983 \\
\hline 0.0013 & 0.9766 \\
\hline 0 & 0.0326 \\
\hline 0.0169 & 0.0511 \\
\hline 0.0293 & 0.1384 \\
\hline 0.0217 & 0.1486 \\
\hline 0.0452 & 0.3480 \\
\hline 0 & 0.1196 \\
\hline
\end{tabular}

0
0.1980
0.1531

0.0297
0.0594
0.0594
0.0693
0.0495
0.2475
3.3366
26453
0.0051
0.7746
0.2085
0.0077
0.0083
0.0495
29324
0.0012
0.7980
0.1963
0.0050
0.0277
0.0478
0.0362
0.1116
0.0010

0
0.4005
0.3619

0.1706
0.2376
0.2376
0.2552
0.2180
0.5178
3.1883
8355
0.0056
0.3067
0.3050
0.0104
0.0029
0.0171
10148
0.0059
0.2899
0.2878
0.0071
0.0054
0.0149
0.0150
0.0519
0.0042

1
0.8125
0.7292

0.6458
0.7292
0.7292
0.1250
1.4792
1.2500
5.7917
46455
0.0154
0.6165
0.3534
0.0111
0.0109
0.0550
74463
0.0157
0.6265
0.3561
0.0083

0.0295
0.0455
0.0505
0.1612
0.0094

\begin{tabular}{cc}
0 &. \\
0.3944 & -8.79 \\
0.4491 & -8.33 \\
& \\
0.4833 & -11.43 \\
0.4491 & -11.91 \\
0.4491 & -11.91 \\
0.3342 & -1.12 \\
2.5515 & -5.61 \\
1.6822 & -5.48 \\
7.5736 & -2.79 \\
34439 & -5.52 \\
0.0204 & -4.70 \\
0.3473 & 2.82 \\
0.3462 & -2.59 \\
0.0137 & -1.69 \\
0.0036 & -4.64 \\
0.0144 & -1.93 \\
89286 & -4.96 \\
0.0223 & -6.03 \\
0.3291 & 3.21 \\
0.3288 & -3.01 \\
0.0086 & -2.48 \\
& \\
0.0057 & -1.86 \\
0.0113 & 0.94 \\
0.0183 & -5.02 \\
0.0716 & -4.77 \\
0.0196 & -4.08 \\
& \\
\hline
\end{tabular}




\begin{tabular}{|c|c|c|c|c|c|c|c|c|c|c|c|}
\hline & & & Iabre As & Propensit & cores mit & taction of & . & & & & \\
\hline County & Prop. Score & Gew 1835 & County & Prop. Score & Gew 1835 & County & Prop. Score & Gew 1835 & County & Prop. Score & Gew 1835 \\
\hline Kusel & 0.00000000 & 0 & Obernburg & 0.00024650 & 0 & Stadtamhof & 0.00564882 & 0 & Kaiserslautern & 0.45123668 & 1 \\
\hline Feuchtwangen & 0.00000000 & 0 & Beilngries & 0.00027400 & 0 & Vilsbiburg & 0.00577924 & 0 & Speyer & 0.50481166 & 1 \\
\hline Neuulm & 0.00000000 & 0 & Gerolzhofen & 0.00034069 & 0 & Aichach & 0.00600040 & 0 & Germersheim & 0.54654626 & 0 \\
\hline Ebermannstadt & 0.00000001 & 0 & Waldmuenchen & 0.00040183 & 0 & Friedberg & 0.00776956 & 0 & Kaufbeuern & 0.62904575 & 1 \\
\hline Marktheidenfeld & 0.00000002 & 0 & Kehlheim & 0.00049445 & 0 & Deggendorf & 0.00863467 & 0 & Zweibruecken & 0.69628186 & 1 \\
\hline Gunzenhausen & 0.00000022 & 0 & Neumarkt & 0.00058634 & 0 & Burglengenfeld & 0.00967336 & 0 & Kempten & 0.74032060 & 1 \\
\hline Sulzbach & 0.00000034 & 0 & Wolfstein & 0.00059623 & 0 & Freising & 0.01477972 & 1 & Eichstaett & 0.88158090 & 0 \\
\hline Ebern & 0.00000046 & 0 & Brueckenau & 0.00067487 & 0 & Dachau & 0.01750575 & 0 & Landshut & 0.88891534 & 1 \\
\hline Forchheim & 0.00000063 & 0 & Grafenau & 0.00067813 & 0 & Wertingen & 0.01894067 & 0 & Wunsiedel & 0.91672999 & 1 \\
\hline Uffenheim & 0.00000169 & 0 & Viechtach & 0.00072822 & 0 & Dingolfing & 0.01923297 & 0 & Straubing & 0.92553182 & 1 \\
\hline Hersbruck & 0.00000408 & 0 & Bogen & 0.00072924 & 0 & Landau & 0.02194617 & 0 & Schweinfurt & 0.95781309 & 1 \\
\hline Karlstadt & 0.00000415 & 0 & Hassfurt & 0.00077826 & 0 & Eschenbach & 0.02534069 & 0 & Amberg & 0.96671162 & 1 \\
\hline Ochsenfurt & 0.00000490 & 0 & Altoetting & 0.00114377 & 0 & Regen & 0.02661892 & 0 & Landau (Bav. Pal.) & 0.96719291 & 1 \\
\hline Mellrichstadt & 0.00000515 & 0 & Hammelburg & 0.00116846 & 0 & Traunstein & 0.02669352 & 0 & Aschaffenburg & 0.98747685 & 1 \\
\hline Pfarrkirchen & 0.00000661 & 0 & Ebersberg & 0.00118243 & 0 & Illertissen & 0.03019956 & 0 & Hof & 0.98778477 & 1 \\
\hline Kulmbach & 0.00000942 & 0 & Wasserburg & 0.00118968 & 0 & Miltenberg & 0.03933754 & 0 & Noerdlingen & 0.99541633 & 1 \\
\hline Hoechstadt & 0.00000984 & 0 & Rottenburg & 0.00172130 & 0 & Cham & 0.03977072 & 0 & Ansbach & 0.99641537 & 1 \\
\hline Miesbach & 0.00001182 & 0 & Koetzting & 0.00204177 & 0 & Kemnath & 0.04152793 & 0 & Fuerth & 0.99777476 & 1 \\
\hline Toelz & 0.00001293 & 0 & Neustadt a.d.S. & 0.00226500 & 0 & Krumbach & 0.05214097 & 0 & Erlangen & 0.99912691 & 1 \\
\hline Tirschenreuth & 0.00001389 & 0 & Stadtsteinach & 0.00236657 & 0 & Muenchberg & 0.05295977 & 0 & Bayreuth & 0.99999642 & 1 \\
\hline Koenigshofen & 0.00001612 & 0 & Eggenfelden & 0.00243651 & 0 & Vilshofen & 0.05300396 & 0 & Passau & 0.99999979 & 1 \\
\hline Fuessen & 0.00002224 & 0 & Roding & 0.00298765 & 0 & Weissenburg & 0.07056789 & 0 & Regensburg & 0.99999982 & 1 \\
\hline Griesbach & 0.00002285 & 0 & Laufen & 0.00301985 & 0 & Landsberg & 0.07376489 & 0 & Augsburg & 1 & 1 \\
\hline Alzenau & 0.00003884 & 0 & Muehldorf & 0.00308007 & 0 & Kronach & 0.08393671 & 0 & Nuernberg & 1 & 1 \\
\hline Heilsbronn & 0.00005147 & 0 & Rosenheim & 0.00318161 & 0 & Primasens & 0.08396556 & 0 & Wuerzburg & 1 & 1 \\
\hline Nabburg & 0.00009205 & 0 & Neunburg v./W. & 0.00338780 & 0 & Vohenstrauss & 0.08852760 & 0 & Bamberg & 1 & 1 \\
\hline Donauwoerth & 0.00010729 & 0 & Weilheim & 0.00343122 & 0 & Guenzburg & 0.11446692 & 0 & Munich & 1 & 1 \\
\hline Sonthofen & 0.00011284 & 0 & Pfaffenhofen & 0.00345250 & 0 & Mindelheim & 0.11967273 & 0 & & & \\
\hline Berneck & 0.00016717 & 0 & Erding & 0.00364939 & 0 & Lichtenfels & 0.12169397 & 0 & & & \\
\hline Lohr & 0.00019007 & 0 & Schongau & 0.00394871 & 0 & Bergzabern & 0.16355072 & 0 & & & \\
\hline Schrobenhausen & 0.00021281 & 0 & Naila & 0.00541374 & 0 & Kirchheimbolanden & 0.25738320 & 0 & & & \\
\hline Hemau & 0.00023576 & 0 & Rehau & 0.00556483 & 0 & Frankenthal & 0.28293294 & 0 & & & \\
\hline
\end{tabular}

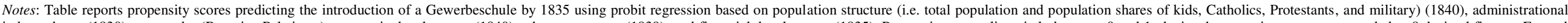

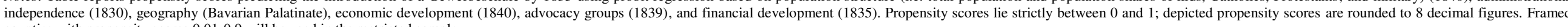
counties with propensity scores $0.01-0.9$ will be used in the restricted sample. 
Table A4 Propensity scores 'Introduction of Realschule by 1896'

\begin{tabular}{|c|c|c|c|c|c|c|c|c|c|c|c|c|c|c|}
\hline County & Prop. Score & Real 1896 & County & Prop. Score & Real 1896 & County & Prop. Score & Real 1896 & County & Prop. Score & Real 1896 & County & Prop. Score & Real 1896 \\
\hline Mellrichstadt & 0.00400615 & 0 & Kemnath & 0.03639299 & 0 & Tirschenreuth & 0.08093628 & 0 & Bergzabern & 0.28549440 & 0 & Freising $^{\mathrm{a}}$ & 0.96877014 & 1 \\
\hline Ebern & 0.01247398 & 0 & Muenchberg & 0.03669276 & 0 & Neunburg v.W. & 0.08328640 & 0 & Kelheim & 0.30327481 & 0 & Fuerth ${ }^{\mathrm{a}}$ & 0.97370412 & 1 \\
\hline Brueckenau & 0.01346932 & 0 & Ochsenfurt & 0.03803134 & 0 & Wasserburg & 0.08742052 & 1 & Guenzburg & 0.30594024 & 0 & Speyer $^{\mathrm{a}}$ & 0.97557420 & 1 \\
\hline Wertingen & 0.01497947 & 0 & Obernburg & 0.03837936 & 0 & Berneck & 0.08800818 & 0 & Aichach & 0.36744534 & 0 & Straubing ${ }^{\mathrm{a}}$ & 0.98338305 & 1 \\
\hline Toelz & 0.01632981 & 0 & Koetzting & 0.03877813 & 0 & Naila & 0.08829156 & 0 & Kulmbach & 0.36964623 & 1 & Ingolstadt $^{\mathrm{a}}$ & 0.98383820 & 1 \\
\hline Zusmarshausen & 0.01750079 & 0 & Ebersberg & 0.03921243 & 0 & Hemau & 0.08990417 & 0 & Kirchheimbolanden & 0.37173112 & 0 & Aschaffenburg $^{a}$ & 0.98827584 & 1 \\
\hline Werdenfels & 0.01754602 & 0 & Cham & 0.03956050 & 0 & Lichtenfels & 0.09304304 & 0 & Traunstein $^{\mathrm{a}}$ & 0.39196065 & 1 & Kempten $^{\mathrm{a}}$ & 0.99554556 & 1 \\
\hline Fuessen & 0.01788620 & 0 & Gerolzhofen & 0.03966480 & 0 & Neuulm & 0.10033038 & 1 & Germersheim & 0.43324553 & 0 & Landshut $^{\mathrm{a}}$ & 0.99948648 & 1 \\
\hline Ebermannstadt & 0.01811158 & 0 & Wolfstein & 0.04121859 & 0 & Erding & 0.10386019 & 0 & Landau (Bav. Pal.) $)^{\mathrm{a}}$ & 0.44827737 & 1 & Schweinfurt ${ }^{\mathrm{a}}$ & 0.99957825 & 1 \\
\hline Krumbach & 0.01837520 & 0 & Bruck & 0.04155280 & 0 & Deggendorf & 0.10504537 & 0 & Mindelheim & 0.45119751 & 0 & Memmingen $\mathrm{a}^{\mathrm{a}}$ & 0.99963047 & 1 \\
\hline Grafenau & 0.01879839 & 0 & Beilngries & 0.04271261 & 0 & Vilshofen & 0.10575927 & 0 & Sonthofen & 0.54060338 & 0 & Ansbach $^{\mathrm{a}}$ & 0.99974722 & 1 \\
\hline Alzenau & 0.02136045 & 0 & Eschenbach & 0.04326968 & 0 & Vilsbiburg & 0.10859287 & 0 & Pirmasens & 0.55205020 & 1 & Passau $^{a}$ & 0.99997742 & 1 \\
\hline Weilheim & 0.02251629 & 1 & Neustadt a.d.S. & 0.04535725 & 0 & Marktheidenfeld & 0.11001622 & 0 & Donauwoerth & 0.55800974 & 0 & Erlangen $^{\mathrm{a}}$ & 0.99999945 & 1 \\
\hline Oberdorf & 0.02360980 & 0 & Koenigshofen & 0.04624243 & 0 & Landau & 0.11066212 & 0 & Uffenheim & 0.57625022 & 0 & Neustadt a.H. ${ }^{a}$ & 0.99999986 & 1 \\
\hline Staffelstein & 0.02404579 & 0 & Velburg & 0.04728804 & 0 & Lohr & 0.11636461 & 0 & Landsberg & 0.60286253 & 1 & Bayreuth $^{\mathrm{a}}$ & 0.99999990 & 1 \\
\hline Berchtesgaden & 0.02423028 & 0 & Illertissen & 0.04737809 & 0 & Forchheim & 0.12432965 & 0 & Zweibruecken ${ }^{a}$ & 0.63993599 & 1 & Regensburg $^{a}$ & 1 & 1 \\
\hline Waldmuenchen & 0.02540181 & 0 & Hoechstadt & 0.05197634 & 0 & Muehldorf & 0.13092165 & 0 & Kaiserslautern ${ }^{\mathrm{a}}$ & 0.64551591 & 1 & Bamberg $^{\mathrm{a}}$ & 1 & 1 \\
\hline Dingolfing & 0.02543323 & 0 & Laufen & 0.05394744 & 0 & Homburg & 0.13867600 & 0 & Rothenburg ${ }^{\mathrm{a}}$ & 0.67425086 & 1 & Nuremberg ${ }^{a}$ & 1 & 1 \\
\hline Nabburg & 0.02637948 & 0 & Vohenstrauss & 0.05482266 & 0 & Griesbach & 0.13917025 & 0 & Wunsiedel $^{\mathrm{a}}$ & 0.72188473 & 1 & Munich $^{a}$ & 1 & 1 \\
\hline Schongau & 0.02664647 & 0 & Hassfurt & 0.05859604 & 0 & Scheinfeld & 0.14116578 & 0 & Weissenburg $^{\mathrm{a}}$ & 0.72605179 & 1 & Wuerzburga $^{a}$ & 1 & 1 \\
\hline Viechtach & 0.02738445 & 0 & Stadtsteinach & 0.05897864 & 0 & Pegnitz & 0.14761744 & 0 & Eichstaett $^{a}$ & 0.74822489 & 1 & Augsburg $^{\mathrm{a}}$ & 1 & 1 \\
\hline Schrobenhausen & 0.02764558 & 0 & Bogen & 0.06111553 & 0 & Hammelburg & 0.16146656 & 0 & Rosenheim & 0.74833617 & 1 & & & \\
\hline Wegscheid & 0.02833802 & 0 & Neustadt (W.N.) & 0.06157970 & 0 & Gunzenhausen & 0.17230658 & 1 & Lindau ${ }^{\mathrm{a}}$ & 0.74992834 & 1 & & & \\
\hline Karlstadt & 0.02983291 & 0 & Mallersdorf & 0.06420841 & 0 & Frankenthal & 0.17730049 & 0 & Kaufbeuren $^{\mathrm{a}}$ & 0.76487790 & 1 & & & \\
\hline Dachau & 0.03106451 & 0 & Stadtamhof & 0.06649176 & 0 & Feuchtwangen & 0.18616549 & 0 & Dinkelsbuehl $^{\mathrm{a}}$ & 0.81085477 & 1 & & & \\
\hline Miesbach & 0.03193912 & 0 & Pfarrkirchen & 0.06680886 & 0 & Rottenburg & 0.19097096 & 0 & Amberg ${ }^{\mathrm{a}}$ & 0.83758968 & 1 & & & \\
\hline Friedberg & 0.03300051 & 0 & Kronach & 0.06703092 & 1 & Miltenberg & 0.22035489 & 0 & Dillingen & 0.84839902 & 0 & & & \\
\hline Heilsbronn & 0.03460483 & 0 & Pfaffenhofen & 0.06938805 & 0 & Kusel & 0.22200859 & 0 & Kitzingen $^{a}$ & 0.86979060 & 1 & & & \\
\hline Teuschnitz & 0.03519672 & 0 & Rehau & 0.07390821 & 0 & Neustadt a.A. & 0.25186034 & 0 & Neuburg ${ }^{a}$ & 0.91023330 & 1 & & & \\
\hline Roding & 0.03568193 & 0 & Neumarkt/Opf. & 0.07441592 & 1 & Kissingen $^{\mathrm{a}}$ & 0.25570521 & 1 & Schwabach & 0.91646409 & 0 & & & \\
\hline Burglengenfeld & 0.03569828 & 0 & Eggenfelden & 0.07520850 & 0 & Hersbruck & 0.26591032 & 0 & Noerdlingen $^{a}$ & 0.92028545 & 1 & & & \\
\hline Regen & 0.03626350 & 0 & Sulzbach & 0.07645861 & 0 & Altoetting & 0.28436290 & 0 & Hof $^{\mathrm{a}}$ & 0.93726518 & 1 & & & \\
\hline
\end{tabular}

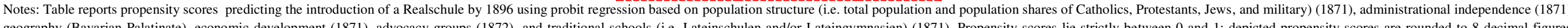

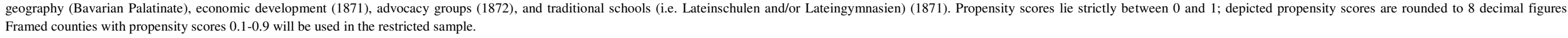
${ }^{\text {a }}$ Realschule in 1877. 